University of South Florida

DIGITAL COMMONS

Digital Commons @ University of

@ UNIVERSITY OF SOUTH FLORIDA

South Florida

$6-15-2000$

\title{
Near-Surface Phytoplankton Distribution in the Western Intra- Americas Sea: The Influence of El Niño and Weather Events
}

Nelson M. Gonzalez

Tecnologia y Medio Ambiente

Frank E. Muller-Karger

University of South Florida, carib@usf.edu

Sergio Cerdeira Estrada

Tecnologia y Medio Ambiente

Roberto Perez de los Reyes

Tecnologia y Medio Ambiente

Ivan Victora del Rio

Tecnologia y Medio Ambiente

See next page for additional authors

Follow this and additional works at: https://digitalcommons.usf.edu/msc_facpub

Part of the Marine Biology Commons

\section{Scholar Commons Citation}

Gonzalez, Nelson M.; Muller-Karger, Frank E.; Estrada, Sergio Cerdeira; de los Reyes, Roberto Perez; del Rio, Ivan Victora; Perez, Pedro Cardenas; and Arenal, Ida Mitrani, "Near-Surface Phytoplankton Distribution in the Western Intra-Americas Sea: The Influence of El Niño and Weather Events" (2000). Marine Science Faculty Publications. 54.

https://digitalcommons.usf.edu/msc_facpub/54

This Article is brought to you for free and open access by the College of Marine Science at Digital Commons @ University of South Florida. It has been accepted for inclusion in Marine Science Faculty Publications by an authorized administrator of Digital Commons @ University of South Florida. For more information, please contact digitalcommons@usf.edu. 


\section{Authors}

Nelson M. Gonzalez, Frank E. Muller-Karger, Sergio Cerdeira Estrada, Roberto Perez de los Reyes, Ivan Victora del Rio, Pedro Cardenas Perez, and Ida Mitrani Arenal 


\title{
Near-surface phytoplankton distribution in the western Intra-Americas Sea: The Influence of El Niño and weather events
}

\author{
Nelson Melo González, ${ }^{1}$ Frank E. Müller-Karger, ${ }^{2}$ Sergio Cerdeira Estrada, ${ }^{1}$ \\ Roberto Pérez de los Reyes, ${ }^{1}$ Iván Victoria del Río, ${ }^{1}$ \\ Pedro Cárdenas Pérez, ${ }^{3}$ and Ida Mitrani Arenal ${ }^{3}$
}

\begin{abstract}
The space-time variation of phytoplankton pigments in the western IntraAmericas Sea (IAS), in the vicinity of the island of Cuba, is examined using digital images obtained with the Coastal Zone Color Scanner sensor flown aboard the Nimbus 7 satellite from 1978 to 1986 . The results are compared to historical in situ hydrographic observations. A marked seasonality in pigment concentration was observed in waters around Cuba, with an average of $0.07 \mathrm{mg} \mathrm{m}^{-3}$ in summer (April-September) and $0.13 \mathrm{mg}$ $\mathrm{m}^{-3}$ during winter (October-March). The range of variation in pigment concentration was larger in the Gulf of Mexico relative to the western Caribbean Sea. We identified four biogeographical areas on the basis of groups of pixels with similar patterns of time variability. These are area I: southwest of Cuba, Yucatan Channel, and Florida Strait; area II: central Gulf of Mexico; area III: east of Cuba; and area IV: central Caribbean Sea, south of Jamaica and Hispaniola. Two major meteorological events led to anomalies in the seasonal cycle of pigment concentrations. During El Niño-Southern Oscillation (ENSO) of 1982-1983, positive anomalies were observed in the pigment concentration in the western IAS during winter months. This was associated with intense mixing of the water column by higher-frequency and stronger winds associated with cold fronts. ENSO 1982-1983 therefore had a fertilizing effect on the IAS region. Another positive anomaly was observed in 1980-1981, a non-ENSO period that featured higher hurricane and extratropical low-pressure activity.
\end{abstract}

\section{Introduction}

There are surprisingly few studies that address patterns in the abundance of phytoplankton in the Intra-Americas Sea (IAS), which includes the Caribbean and the Gulf of Mexico. Perhaps this is because this semienclosed tropical basin is traditionally considered to be oligotrophic [Margalef, 1969; Corredor, 1977]. On the basis of studies of Coastal Zone Color Scanner (CZCS) satellite data, however, we know that the Gulf of Mexico undergoes pronounced seasonal variation in phytoplankton standing stocks. This seasonality is driven in summer by high stability of the water column (low pigment concentrations) and by convective cooling and stronger winds during winter (high concentrations) [Müller-Karger et al., 1991; Melo et al., 1995]. The southeastern Caribbean also experiences seasonal variability in pigment abundance, with wind-driven upwelling leading to high concentrations along its southern margin during boreal winter and spring. The widespread plume formed by the discharge of the Orinoco River leads to higher phytoplankton biomass and dissolved organic concentrations

\footnotetext{
${ }^{1}$ Instituto de Oceanología, Ministerio de Ciencia, Tecnología y Medio Ambiente, Havana, Cuba.

${ }^{2}$ Department of Marine Science, University of South Florida, St. Petersburg.

${ }^{3}$ Instituto de Meteorología, Ministero de Ciencia, Tecnología y Medio Ambiente, Havana, Cuba.

Copyright 2000 by the American Geophysical Unıon.

Paper number 2000JC900017.

0148-0227/00/2000JC900017\$09.00
}

throughout the central-eastern Caribbean during boreal fall [Müller-Karger et al., 1989; Müller-Karger and Aparicio Castro, 1994]. There is little information available on the western Caribbean, however. Jromov [1967], on the basis of very few historical observations, concluded that plankton levels there are very low and seasonally invariant.

One of the most important events that influence global climate is the El Niño-Southern Oscillation (ENSO). Around Cuba, anomalies in atmospheric pressure, rainfall, and air temperatures have been linked to ENSO [Cárdenas and Naranjo Diaz, 2000a]. Some of the most obvious changes experienced in the IAS during ENSO are decreases in cyclone activity in summer and increases in extratropical storm systems in winter. CZCS data cover the 1982-1983 ENSO. Here we present evidence that maxima in the concentration of pigments in 19821983 in the western IAS coincided with this ENSO event, which was classified as one of the strongest of the century [Hanson and Maul, 1991].

\section{Materials and Methods}

\subsection{CZCS Image Processing}

The CZCS provides a measure of the solar irradiance reflected by the surface layer of the sea in several visible bands. These measurements of the color of the sea are empirically related to the near-surface concentration of phytoplankton pigments [see Morel and Prieur, 1977; Gordon et al., 1983a, b, 1988; Gordon and Wang, 1994; McClain et al., 1995; O'Reilly et al., 1998]. We estimated pigment concentration for the IAS 


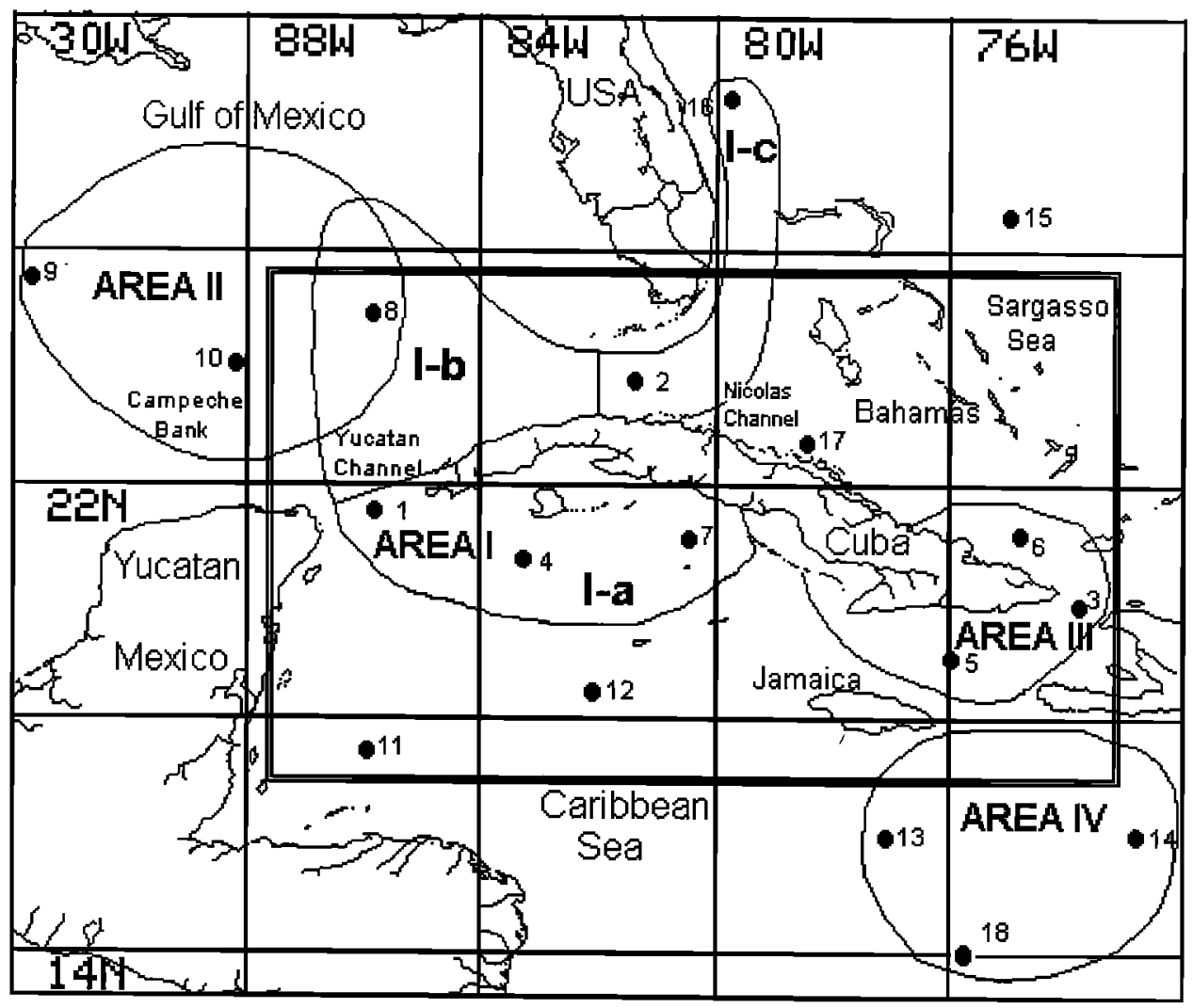

Figure 1. Geographical location of the stations used for time series extractions from the Coastal Zone Color Scanner (CZCS) data and regions identified as behaving as distinct zones in their pigment variability. Zone $\mathrm{I}$ is subdivided into areas I-a, I-b, and I-c. The double line outlines a window where sea surface temperatures were processed.

region using the Gordon et al. [1983a, b] algorithms on all the available CZCS data (November 1978 through July 1986) using programs written for the "dsp" environment developed at the University of Miami. The images were all mapped to a cylindrical equidistant projection with limits of $18^{\circ}-26^{\circ} \mathrm{N}$ and $73^{\circ}-$ $88^{\circ} \mathrm{W}$ (Figure 1 ). We then generated 869 daily composite images covering portions of the IAS at $16 \mathrm{~km}^{2}$ pixel resolution (4 $\mathrm{km} \times 4 \mathrm{~km}$ ). This effort was carried out at the Department of Marine Science, University of South Florida.

The images contain estimates of the concentration of pigments in the first optical depth at each pixel, which in areas of low concentrations $\left(0.04-0.5 \mathrm{mg} \mathrm{m}^{-3}\right)$, represent the average concentration to depths of between 1 and $\sim 15 \mathrm{~m}$ depending on water clarity. Areas with no data, land, or clouds or areas with high reflectance due to the influence of the bottom or sunglint were eliminated by masking. In relatively clear oceanic waters the accuracy of the CZCS product is expected to be of order $30-40 \%$ of the concentration of pigments [Gordon et al., 1982, 1983b]. In coastal areas these concentrations are less reliable and should only be considered qualitatively [Barale et al., 1986].

Given the extensive cloud cover that affected the region during the period of the operation of the CZCS, coherent patterns in concentration of pigment were difficult to observe in single or even weekly CZCS composites. Therefore images were averaged to derive 92 separate monthly means over the period of observation. We also derived mean trimester images (January-March, April-June, July-September, and OctoberDecember), incorporating each of the respective trimesters between 1978 and 1986 (Plate 1). Average "winter" (October-
March) and "summer" (April-September) images and an overall mean of all images were also calculated (Plate 2).

To help with visualization of the gradients in pigment concentration, we defined a palette with 256 colors, which shows maximum contrast for the range $0.04-2.25 \mathrm{mg} \mathrm{m}^{-3}$. Low concentrations are represented in the images as purple or blue, and areas with higher concentrations appear as green, yellow, orange, or red. Higher values in the IAS region are associated primarily with coastal or shallow shelf regions and are represented here in gray scale. The CZCS algorithm may overestimate the concentration of pigments on the continental shelves of Cuba, the Bahamas, and shallow regions near Florida. Field observations suggest that these waters are case II type [cf. Morel and Prieur, 1977]. Missing data or land areas are colored black and dark gray.

To evaluate time variability in pigment concentration, we sampled 18 stations in each of the 92 monthly average images (Figure 1 and Table 1). At each station we extracted a 3 pixel $x$ 3 pixel matrix of valid data $(\sim 12 \mathrm{~km} \times 12 \mathrm{~km})$. The time series provided pigment concentration mean, standard deviation, and range range (maximum and minimum) in the region (Table 1). We computed a multiple correlation matrix to study the degree of similarity between the 18 stations. We used a frequency filter (12 month lag moving average seasonal decomposition filter) on each of the 18 series to remove the seasonal signal in an effort to examine interannual-scale variations.

Some of our sampling stations showed gappy time series. The gaps were more frequent in summer, probably because of cloud cover and increased chances of sunglint. An analysis of 
Table 1. Statistical Parameters Derived for Each of the 18 CZCS Pigment Concentration Time Series Stations

\begin{tabular}{|c|c|c|c|c|c|c|c|c|c|c|c|c|c|c|c|c|c|c|}
\hline & \multicolumn{18}{|c|}{ Station Number } \\
\hline & 1 & 2 & 3 & 4 & 5 & 6 & 7 & 8 & 9 & 10 & 11 & 12 & 13 & 14 & 15 & 16 & 17 & 18 \\
\hline Number of samples, $\mathbf{n}$ & 79 & 85 & 65 & 75 & 67 & 72 & 78 & 78 & 62 & 78 & 56 & 67 & 44 & 39 & 69 & 66 & 78 & 16 \\
\hline $\begin{array}{l}\text { Pigment mean, } \\
\mathrm{mg} \mathrm{m}^{-3}\end{array}$ & 0.100 & 0.098 & 0.066 & 0.081 & 0.076 & 0.072 & 0.076 & 0.105 & 0.120 & 0.120 & 0.090 & 0.085 & 0.087 & 0.100 & 0.076 & 0.121 & 0.148 & 0.091 \\
\hline $\begin{array}{l}\text { Standard Deviation, } \\
\mathrm{mg} \mathrm{m}^{-3}\end{array}$ & 0.046 & 0.052 & 0.028 & 0.034 & 0.035 & 0.030 & 0.034 & 0.055 & 0.064 & 0.056 & 0.040 & 0.039 & 0.039 & 0.061 & 0.036 & 0.060 & 0.069 & 0.042 \\
\hline Minimum, $\mathrm{mg} \mathrm{m}^{-3}$ & 0.041 & 0.041 & 0.041 & 0.041 & 0.041 & 0.041 & 0.041 & 0.041 & 0.045 & 0.041 & 0.041 & 0.041 & 0.041 & 0.041 & 0.041 & 0.049 & 0.053 & 0.046 \\
\hline Maximum, $\mathrm{mg} \mathrm{m}^{-3}$ & 0.328 & 0.280 & 0.150 & 0.169 & 0.209 & 0.199 & 0.183 & 0.292 & 0.352 & 0.315 & 0.237 & 0.224 & 0.186 & 0.290 & 0.192 & 0.307 & 0.355 & 0.198 \\
\hline Range, $\mathrm{mg} \mathrm{m}^{-3}$ & 0.287 & 0.239 & 0.109 & 0.128 & 0.168 & 0.158 & 0.142 & 0.251 & 0.307 & 0.274 & 0.196 & 0.183 & 0.145 & 0.249 & 0.151 & 0.258 & 0.302 & 0.152 \\
\hline
\end{tabular}

cloud cover in the monthly images shows that the clouds' spatial distribution is random over much of the region. However, the Loop Current in the Gulf of Mexico tends to have more clouds than surrounding waters. We expect, nevertheless, that cloud distribution and lack of scheduled satellite CZCS image coverage had a minor effect on our conclusions on spatial or temporal patterns.

\subsection{In Situ Observations}

In situ measurements were collected within 200 nautical miles of the coast of Cuba at 80 stations during four cruises of the $\mathrm{R} / \mathrm{V}$ Ulises. Two cruises were carried out during winter (October-November 1988 and February-March 1989), and two were carried out during summer (May-June and July 1989). Samples for phytoplankton taxonomy and biomass analyses were collected at the surface. Taxonomic analyses were based on 5-12 L samples filtered through nucleopore filters. Only cells $>10 \mu \mathrm{m}$ were identified, using the method proposed by Sorokin [1979]. Pigment concentration (chlorophyll a) was estimated spectrophotometrically, according to Jeffrey and Humphrey [1975] and as modified by Koblentz-Mishke and Vedernikov [1977a, b] [Pérez et al., 1990].

Nutrients and physical characteristics of the water between 0 and $200 \mathrm{~m}$ were also obtained [Fernández et al., 1990; Victoria et al., 1990]. The average insolation was calculated from the New National Atlas of Cuba [Academy Sciences of Cuba (ACC), 1989]. Sea surface temperature (SST) and its anomalies between 1978 and 1986 were examined using data from Reynolds [1988], Reynolds and Marsico [1993] and the Comprehensive Ocean-Atmosphere Data Set (available at http://www.cdc. noaa.gov/coads/). The data from Reynolds [1988] and Reynolds and Marsico [1993] include in situ data, satellite data, and a blended analysis for the subregion outlined within our study area in Figure 1. The in situ data include ship and buoy data summarized in $2^{\circ}$ latitude by $2^{\circ}$ longitude cells. The blended analysis was carried out using a statistical technique suggested by Oort and Rasmusson [1971]. Meteorological parameters and information on hurricanes, cold fronts, and extratropical lowpressure systems were taken from synoptic weather charts and historical logs of the Institute of Meteorology of Cuba (INSMET) and from National Oceanic and Atmospheric Administration buoy $42003\left(25.94^{\circ} \mathrm{N}, 85.91^{\circ} \mathrm{W}\right)$ located in the eastern Gulf of Mexico. The occurrence of ENSO events was defined on the basis of index postings by the NOAA Climate Prediction Center and by INSMET [Cárdenas and Naranjo Díaz, 2000b].

\section{Results and Discussion}

\subsection{Pigment Variability}

Our analyses of the CZCS-derived time series of stations identify at least four separate regions on the basis of their variability in phytoplankton pigment concentration. We grouped stations (Figure 1) when the cross-correlation factor $r$ exceeded 0.65 . Specifically, the areas identified were area I: western Caribbean (southwest of Cuba), southeastern Gulf of Mexico, Yucatan Channel, and Florida Strait (stations 1, 2, 4, 7, 8, and 16); area II: central Gulf of Mexico (stations 8, 9, and 10); area III: northwestern Atlantic coasts, Windward Passage, and Mona Passage (stations 3, 5, and 6); and area IV: central Caribbean (stations 13,14, and 18). Below we describe the major patterns of variability observed within each of these regions.

3.1.1. Area I. Waters flowing from the western Caribbean influence this region. Waters are warm and stratified, and strong currents such as the Yucatan, Loop, and Florida Currents dominate their characteristics. The annual mean pigment concentration is $0.09 \mathrm{mg} \mathrm{m}^{-3}$. Moderate seasonality is observed in the pigment concentration, with maxima between October and March (average of $0.16 \mathrm{mg} \mathrm{m}^{-3}$ ) and minima between April and September (average of $0.06 \mathrm{mg} \mathrm{m}^{-3}$ ). The seasonal average CZCS images (Plates 1a-1d) clearly show that pigment concentrations in this region are lower than those in the interior of the gulf on a year-round basis. Annual mean pigment concentrations in the Loop Current and the Gulf Stream are slightly higher than those in the western Caribbean Sea. At stations 1 and 2, which represent the Yucatan Channel and Florida Strait, respectively, seasonal changes in the intensity of the flow are known to be in phase [Maul and Vukovich, 1993]. Somewhat larger velocities are observed during warm months of the year [Gordon, 1967]. Transport is $>25 \mathrm{~Sv}$, and upwelling is frequently observed along the cyclonic edge of the flow within the channels [Pérez et al., 1996, 1999]. Phytoplankton blooms are observed along the western edge of the Yucatan Channel year-round. The blooms extend along the edge of the Loop Current, from Campeche Bank and into the interior of the Gulf of Mexico, and around the edge of the Loop Current. Alternatively, discolorations may trace entrainment of Mississippi River Water around the eastern half of a fully extended Loop Current [Müller-Karger et al., 1991]. Figure 2 shows the time series of pigment concentration at stations classified as belonging to area $\mathbf{I}$. The increase in chlorophyll concentration in winter takes place as thermal stability weakens, which leads to enhanced vertical nutrient supply from 


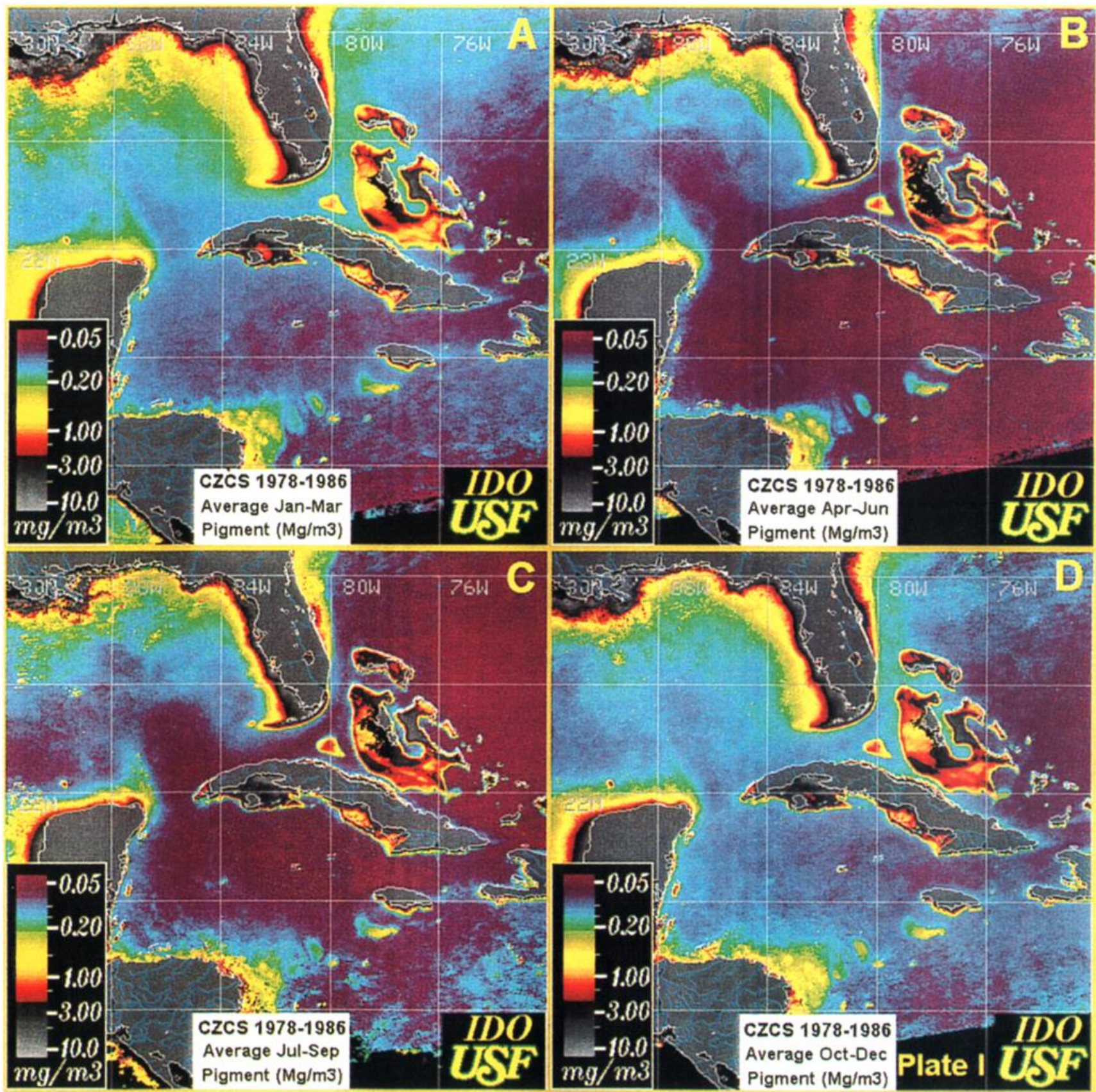

Plate 1. CZCS composites showing pigment concentrations during (a) January-March, (b) April-June, (c) July-September, and (d) October-December, 1978-1986.

below [Müller-Karger et al., 1991; Pérez et al., 1990, 1999; Victoria et al., 1990; Fernández et al., 1990].

3.1.2. Area II. Area II includes waters of the central Gulf of Mexico and is heavily influenced by the Loop Current and its eddies. Pigment concentration in the three separate stations behaves very similarly indeed (Figure 3). Station 8 may be classified as belonging to area I or area II, depending on the position of the Loop Current and its rings. The annual mean pigment concentration of area II $\left(0.12 \mathrm{mg} \mathrm{m}^{-3}\right)$ is larger than that of Area I, but it is also more variable. Figure 3, nevertheless, shows a remarkable seasonality in the concentration of pigments, with maxima in winter (average of $0.20 \mathrm{mg} \mathrm{m}^{-3}$ ) and minima in summer (average of $0.08 \mathrm{mg} \mathrm{m}^{-3}$ ). The winter increase in pigment concentration is due to fertilization of surface layers by thermal convection and strong winds [Müller-Karger et al., 1991; Victoria et al., 1990]. Frequent and intense cold fronts that carry storms with strong winds and high precipitation $[A C C, 1989]$ are observed here during winter because of the proximity to the continent. The contribution of the Mississippi River is also important in raising pigment concentration because of streamers entrained along the edge of the Loop Current [Müller-Karger et al., 1991; Thomas and Simmons, 1960].

3.1.3. Area III. Waters east of Cuba (area III) have a much smaller mean and seasonal range in pigment concentration than the other areas. The annual mean here is $0.07 \mathrm{mg}$ $\mathrm{m}^{-3}$, with summer values of $0.06 \mathrm{mg} \mathrm{m}^{-3}$ and winter values of $0.09 \mathrm{mg} \mathrm{m}^{-3}$ (Figure 4). This region is less influenced by 

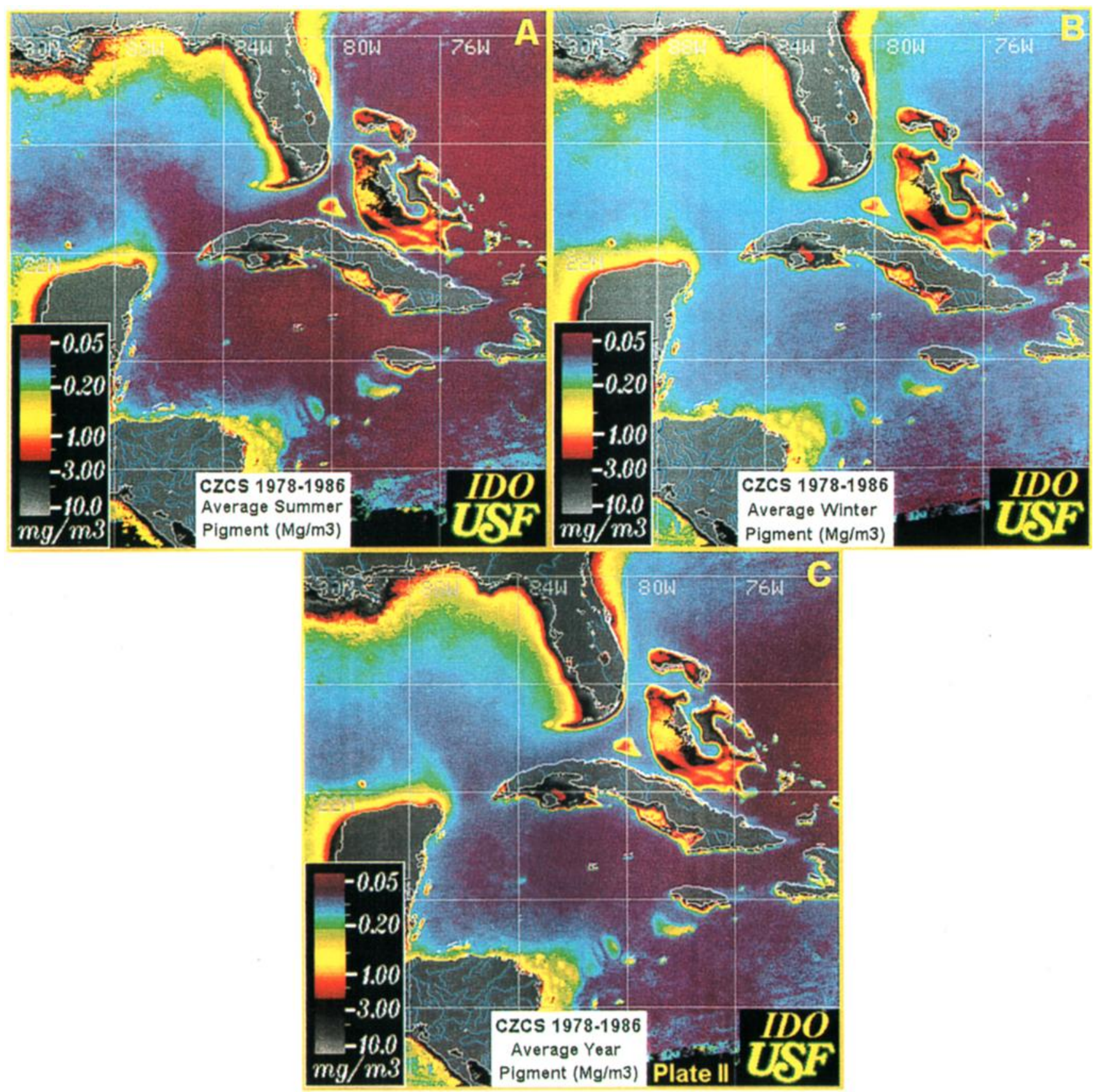

Plate 2. CZCS composites showing (c) pigment concentrations during summer (April-September), (b) pigment concentrations during winter (October-March), and (c) mean pigment concentrations in the region during 1978-1986.

seasonal continental meteorological variations, and cold winter fronts are more rare. Windward Passage is an important entry point of Atlantic Ocean waters to the Caribbean. The water that enters near the surface, which originates in the Sargasso Sea, is low in nutrients and plankton concentration.

Flow through the Caribbean and through island passes increases between February and July [Gordon, 1967]. Waters with extremely low pigment concentration enter through Windward Passage in March-May, as can be seen in a jet of extremely clear water traced in CZCS images. Stations 3, 5, and 6 are directly influenced by this flow, and their variability in pigment concentration is dominated by the exchange regime between the Caribbean and the adjacent Sargasso Sea.
3.1.4. Area IV. Area IV includes waters south of Jamaica and Hispaniola in the central Caribbean Sea. The annual average pigment concentration is $0.09 \mathrm{mg} \mathrm{m}^{-3}$, with a range of $0.07-0.12 \mathrm{mg} \mathrm{m}^{-3}$ (Figure 5). This is the region for which we had the fewest images because of cloud cover and lack of scheduled CZCS image coverage (the instrument was rarely turned on over this area), and therefore it was harder to establish seasonal ranges in concentrations.

The CZCS time series (Figures 2-5) show that gaps were more likely to occur in summer. Plates $1 \mathrm{a}-1 \mathrm{~d}$ combine several years of CZCS images. The images show lowest pigment density in April-June in area IV, i.e. prior to the arrival of colored water from the Orinoco and Amazon River plumes [cf. Müller- 


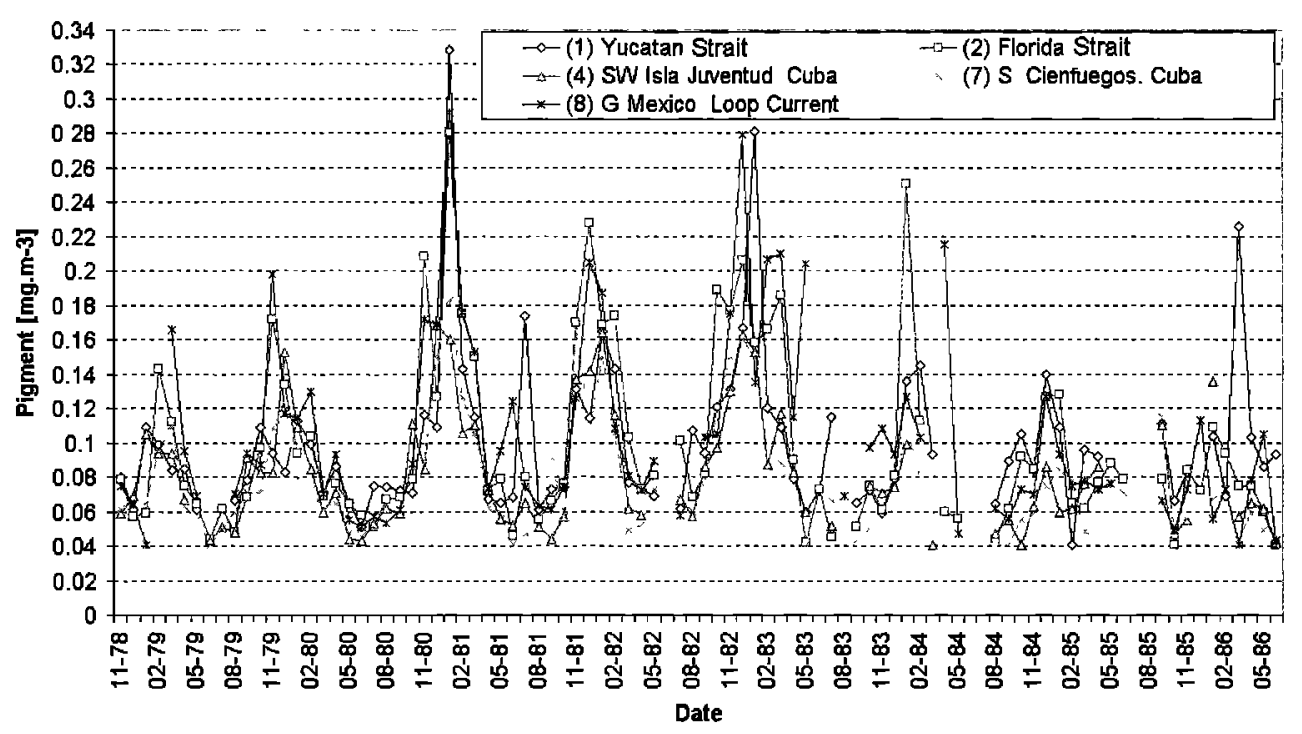

Figure 2. Seasonal variation of the concentration of pigments in area I.

Karger et al., 1989] and after the winter convective overturn of the upper water column. Area IV, in general, experiences low transport as it is located in the northern half of the Caribbean Current, which is characterized by speeds of $\sim 40 \mathrm{~cm} \mathrm{~s}^{-1}$ at its northernmost extent [Wüst, 1964]. This is much less than speeds in areas I and II. Also, downwelling due to the curl of the wind stress characterizes the northern half of the Caribbean [Müller-Karger and Aparicio Castro, 1994]. Surface waters therefore experience little to no replenishment of nutrients from below.

\subsection{Pigment Time Variability}

During the first quarter of the year (January-March; Table 2, Plate 1a), maxima in pigment concentration are seen everywhere in the northwestern Caribbean Sea and Gulf of Mexico as a result of nutrient fertilization by wind mixing, thermal convection, and upwelling such as along the Bank of Campeche [Merino, 1992; Pérez et al., 1999]. The presence of the Florida Current and the Loop Current are seen clearly as their waters are traced by the lower concentrations of pigments coming from the western Caribbean. In and around Windward Passage, off eastern Cuba, waters with a low concentration of pigments $\left(0.07 \mathrm{mg} \mathrm{m}^{-3}\right)$ relative to the rest of our area of study may be seen flowing westward from the Sargasso Sea. In the Old Bahamas Channel and in the channels of San Nicolás and Santarén (north of the Sabana-Camagüey Archipelago, off north central Cuba), higher concentrations of pigments are observed (0.12-0.28 $\left.\mathrm{mg} \mathrm{m}^{-3}\right)$. This may be due to an exchange between the open ocean and shallow areas that are rich in nutrients on the platform of Cuba and Bahamas [Fernández and Chirinos, 1993], but it also could be due to upwelling, as suggested by cooler SST patches observed frequently in infrared advanced very high resolution radiometer satellite images.

The second quarter (April-June; Table 2, Plate 1b) brings a decrease in pigment levels over the whole area, except off the northern Yucatan Peninsula. There, values of $0.12-0.30 \mathrm{mg} \mathrm{m}^{-3}$ are observed because of the Campeche bank upwelling [Pérez et

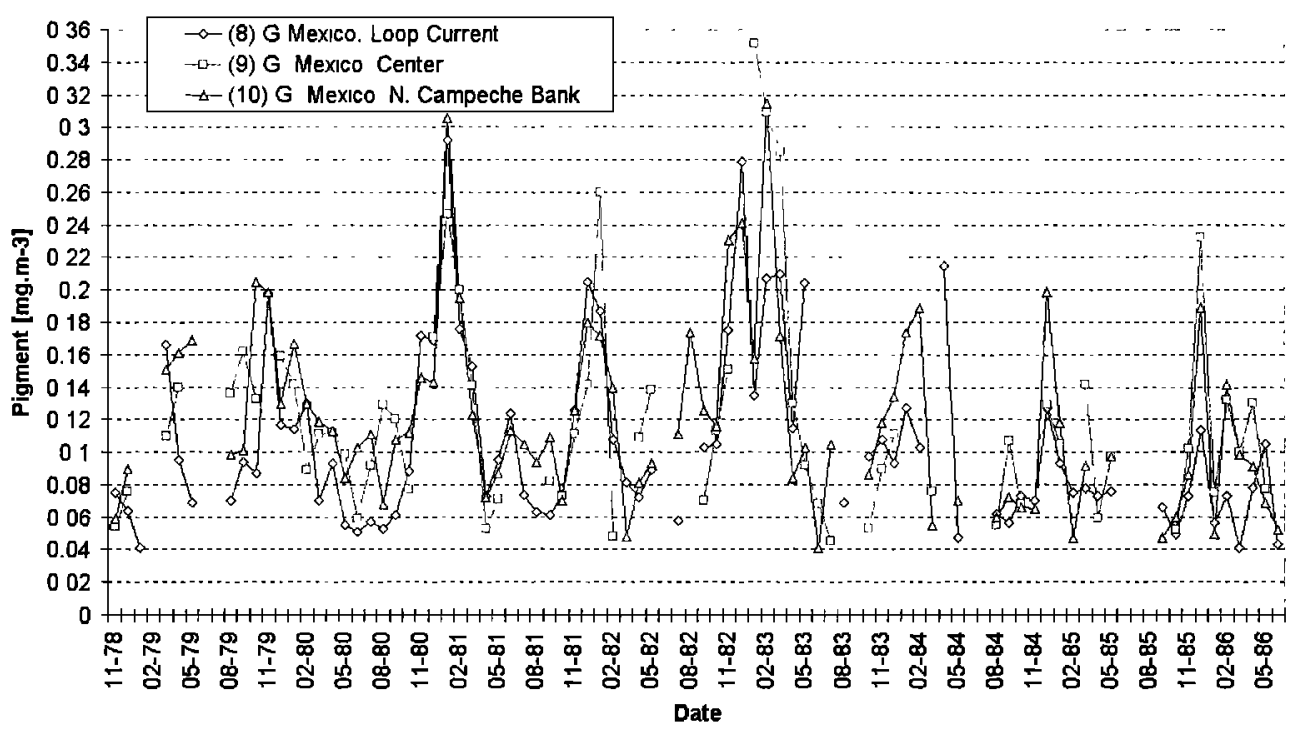

Figure 3. Seasonal variation of the concentration of pigments in area II. 


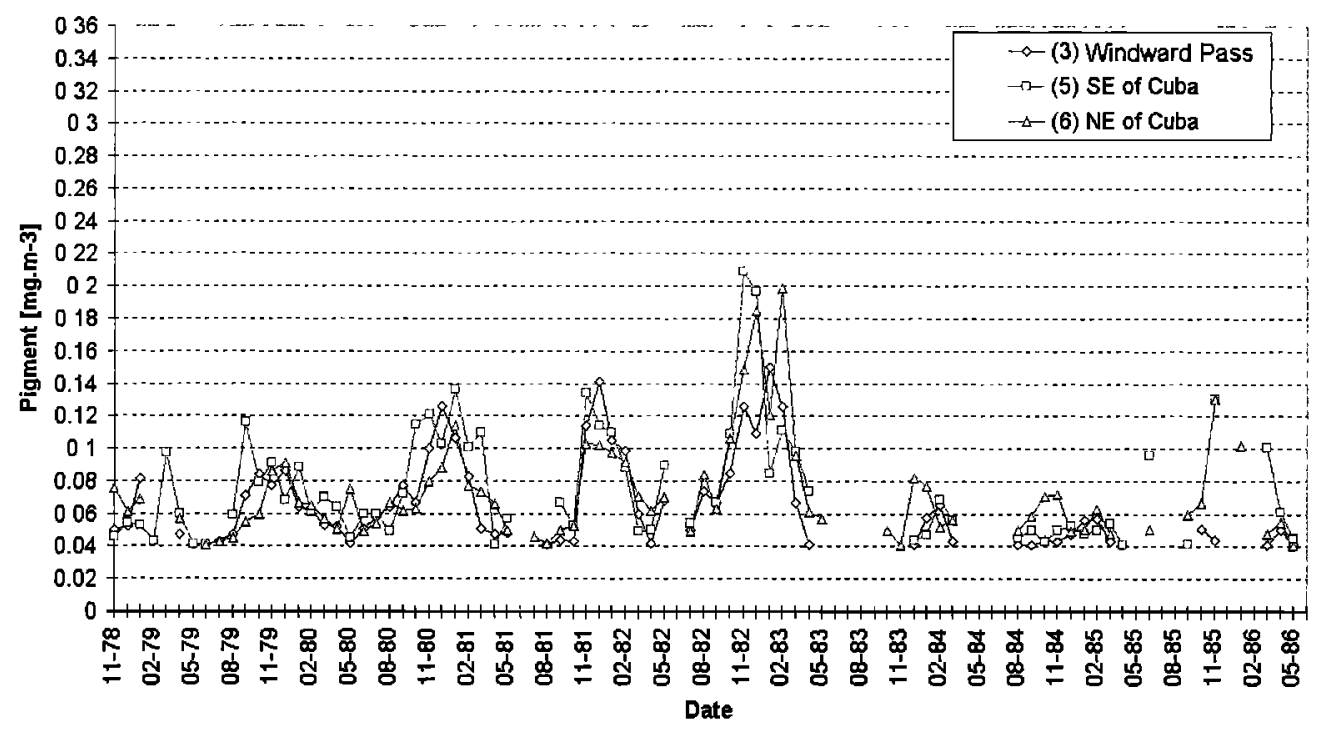

Figure 4. Seasonal variation of the concentration of pigments in area III.

al., 1999]. In the western Caribbean the mean pigments reach their lowest annual values at $0.065 \mathrm{mg} \mathrm{m}^{-3}$. Maxima (values $>0.12 \mathrm{mg} \mathrm{m}^{-3}$ ) are seen only near coasts. In the Gulf of Mexico, values from 0.08 to $0.15 \mathrm{mg} \mathrm{m}^{-3}$ are seen, with maxima $(>0.20$ $\mathrm{mg} \mathrm{m}^{-3}$ ) in the Mississippi River plume and on the West Florida shelf. Clearly, some of these features like the river plume represent case II waters [Morel and Prieur, 1977], and the CZCS may have overestimated actual pigment concentrations.

In the third quarter (July-September; Table 2, Plate 1c), pigments are low in the entire extreme northwestern Caribbean and in the Loop Current, but values in the Gulf of Mexico outside of the Loop Current are relatively high. High concentration patches are widely spread over the central Caribbean $\left(0.12-0.16 \mathrm{mg} \mathrm{m}^{-3}\right)$ as the Orinoco River plume begins to disperse westward [Müller-Karger et al., 1989]. This plume carries high concentrations of dissolved organic material as well as phytoplankton [Hochman et al., 1994].
In the fourth quarter (October-December; Table 2, Plate 1d), concentrations of pigments over the entire region, including the western Caribbean, increase $\left(0.08-0.15 \mathrm{mg} \mathrm{m}^{-3}\right)$. The northern front of the Loop Current loses definition because concentration gradients become more diffuse. Southeast of Cuba, waters with lower concentrations of pigments $(0.07-0.10$ $\mathrm{mg} \mathrm{m}^{-3}$ ) are observed coming from the Sargasso Sea via Windward Passage. Maxima are observed in the Gulf of Honduras and to the northeast of the Yucatan Peninsula.

The average of all the CZCS data (Plate 2c) shows a minimum $\left(0.06-0.08 \mathrm{mg} \mathrm{m}^{-3}\right)$ in the pigment concentration fields in the western Caribbean near $18^{\circ}-20^{\circ} \mathrm{N}, 74^{\circ}-80^{\circ} \mathrm{W}$. This large area with very low values is encompassed by the Windward Passage and the Sargasso Sea. Immediately south of Cuba, pigments show a slight increase from east to west of 0.07 to $0.12 \mathrm{mg} \mathrm{m}^{-3}$. Clear Sargasso Sea waters dominate east of Cuba, with a mean concentration of pigments of $\sim 0.07 \mathrm{mg}$

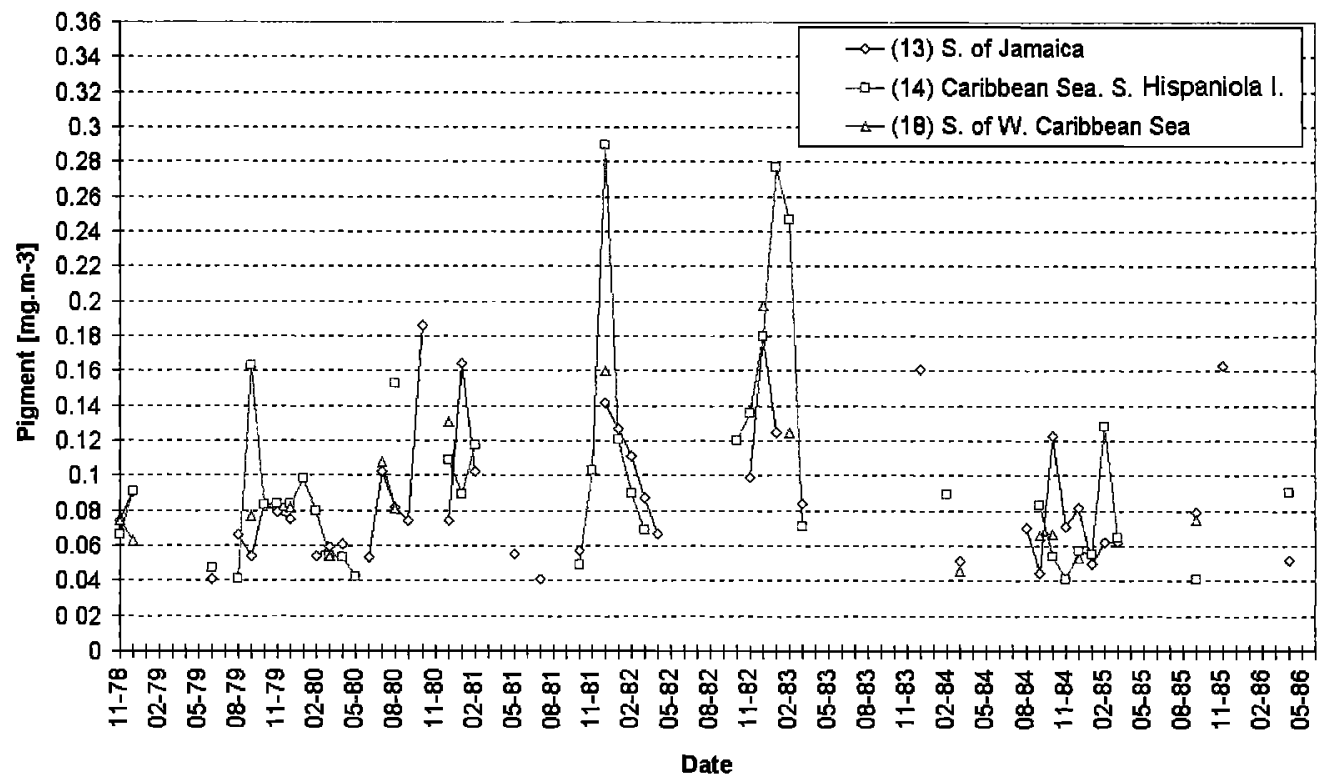

Figure 5. Seasonal variation of the concentration of pigments in area IV. 
Table 2. Average Range of Variation in the Concentration of Pigments in CZCS Data

\begin{tabular}{lccccccc}
\hline & Jan.-March & April-June & July-Sept. & Oct.-Dec. & Winter & Summer & Annual \\
\hline Western Caribbean & $0.07-0.15$ & $\mathbf{0 . 0 5 - 0 . 0 8}$ & $0.06-0.10$ & $0.07-0.13$ & $0.08-0.15$ & $0.06-0.09$ & $0.07-0.15$ \\
Gulf of Mexico & $\mathbf{0 . 1 0 - 0 . 5 0}$ & $\mathbf{0 . 0 7 - 0 . 3 0}$ & $0.06-0.20$ & $\mathbf{0 . 0 9 - 0 . 3 5}$ & $\mathbf{0 . 1 1 - 0 . 5 0}$ & $0.07-0.30$ & $0.09-0.50$ \\
Sargasso Sea & $0.06-0.09$ & $\mathbf{0 . 0 4 - 0 . 0 6}$ & $0.04-0.06$ & $\mathbf{0 . 0 6 - 0 . 0 8}$ & $0.07-0.09$ & $\mathbf{0 . 0 4 - 0 . 0 7}$ & $0.04-0.09$ \\
\hline
\end{tabular}

$\mathrm{m}^{-3}$. The low pigment concentration serves also as a tracer of the Loop Current in the Gulf of Mexico.

The Campeche Bank, off the Yucatan Peninsula, shows high pigment concentrations year-round. This upwelling zone frequently spans over $300 \mathrm{~km}$ along the Yucatan Peninsula and reaches $100 \mathrm{~km}$ offshore.

\subsection{In Situ Observations}

On the basis of in situ observations carried out aboard the R/V Ulises between 1988 and 1989 the summer upper mixed layer south of Cuba is on average $40 \mathrm{~m}$ deep (Table 3) [Victoria et al., 1990]. The spatial averages and seasonal chlorophyll concentration ranges obtained in situ (Figure 6) are similar to the values derived from the CZCS satellite sensor (Table 4) [Pérez et al., 1990] in spite of the dissimilar methods and sampling time (different years). The comparison confirmed the temporal tends in chlorophyll concentration in the region. In winter, intense convective mixing takes place in the region as insolation and air temperatures decrease and wind intensity increases. This leads to a mixed layer of $\sim 110 \mathrm{~m}$ (Table 4 ) [Victoria et al,. 1990], which favors nutrient entrainment into the euphotic zone [Fernández et al., 1990]. While incident solar radiation decreases, light intensity is still sufficiently high to stimulate phytoplankton even in December and January. Given nutrient availability, phytoplankton concentration and diversity are high during winter months in the region (Table 4) [Pérez et al., 1990; Vinogradov and Shushkina, 1987]. In summer, higher insolation and a decrease in wind forcing cause strong thermal stratification and a decrease in vertical mixing, nutrient entry into the euphotic zone, and phytoplankton concentrations throughout most of the region [Müller-Karger et al., 1991].

\subsection{Time Variability and Meteorological Factors}

Figure 7 shows the seasonal signal present in the time series of pigment concentrations for areas I, II, and III. This "averaged" seasonal signal was removed from the entire CZCSderived time record using a 12 month moving average filter to obtain the anomalies shown in Figure 8. Pigment concentrations increase from area III (Windward Passage) to area I (Loop Current) and are highest in area II (Gulf of Mexico outside of the Loop Current). Figure 8 also shows strong interannual variability in pigment concentrations and that this variability is coherent within the western IAS. Two significant maxima were observed in all areas: one in July 1980 to June 1981 and one in April 1982 to October 1983. We were interested in establishing the relationship between these changes and environmental factors. In our analysis we assume that the anomalies observed after removing the seasonal means are not affected by changes in the calibration of the CZCS [Evans and Gordon, 1994]. Our assumption is supported by the CZCSsediment flux studies of Deuser et al. [1990].

There are two meteorological phenomena that generally lead to strong winds within the study region. One is hurricanes, which occur in the Atlantic Ocean and in the IAS during summer. The hurricane season is June 1 to November 15, although cyclones can occur outside this period [Ortiz, 1975]. September and October are the most active months for cyclones affecting the marine environment around Cuba. The other important phenomenon is cold fronts that affect the northwestern IAS in winter. These fronts are characterized by an advance of cold and dry air from the North American continent. Winds associated with these fronts are very forceful and can occasionally reach hurricane strength, mixing waters along the northern coasts of Cuba vigorously. These frontal systems occur from October through April, although some have occurred in September and May. The highest frequency of front-related storms is in December-February, with a maximum in January. The average number of cold fronts affecting Cuba is of the order of 20 each year [Rodriguez et al., 1984]. Typically, $84 \%$ of the fronts are of moderate intensity, and their frequency decreases from west to east.

To examine the impact of these meteorological phenomena on the concentration of pigments in the western IAS, we use the biogeographical zoning (Figure 1) defined earlier on the basis of the time series of pigment concentrations. Area I was subdivided into subregions I-a, I-b, and I-c, representing areas of influence of the intense meteorological factors.

\subsection{Hurricanes}

We reviewed the occurrence of cyclones between 1978 and 1986 using synoptic charts of trajectories from INSMET. During the life of the CZCS, we found the following: A total of 16 disturbances occurred in 1978; 5 were limited to tropical depression and 11 spun up to hurricanes. However, none of these were registered in our study areas. The next year, 1979, was an average season ( 6 depressions and 8 hurricanes), but significant impact was felt in the IAS. Most storms developed be-

Table 3. Mean Characteristics of Oceanic Waters South of Cuba Based on in Situ Observations Carried out Aboard the R/V Ulises Between 1988 and 1989

\begin{tabular}{lccccc}
\hline & $\begin{array}{c}\text { Global Solar } \\
\text { Radiation, } \\
\mathrm{mjm}^{-2} \mathrm{~d}^{-1}\end{array}$ & $\begin{array}{c}\text { Mixed Layer } \\
\text { Thickness, } \\
\mathrm{m}\end{array}$ & $\begin{array}{c}\text { Temperature, } \\
{ }^{\circ} \mathrm{C}\end{array}$ & $\begin{array}{c}\text { Nitrogen } \\
\text { Concentration } \\
\mathrm{NO}_{2}+\mathrm{NO}_{3}, \\
\mu \mathrm{mL}^{-1}(0-200 \mathrm{~m})\end{array}$ & $\begin{array}{c}\text { Phosphate } \\
\text { Concentration } \mathrm{PO}_{4}, \\
\mu \mathrm{mL}^{-1}(0-200 \mathrm{~m})\end{array}$ \\
\hline Winter & 14.2 & $100-125$ & 26.0 & 1.06 & 0.14 \\
Summer & 19.3 & $30-50$ & 29.7 & 0.95 & 0.05 \\
\hline
\end{tabular}



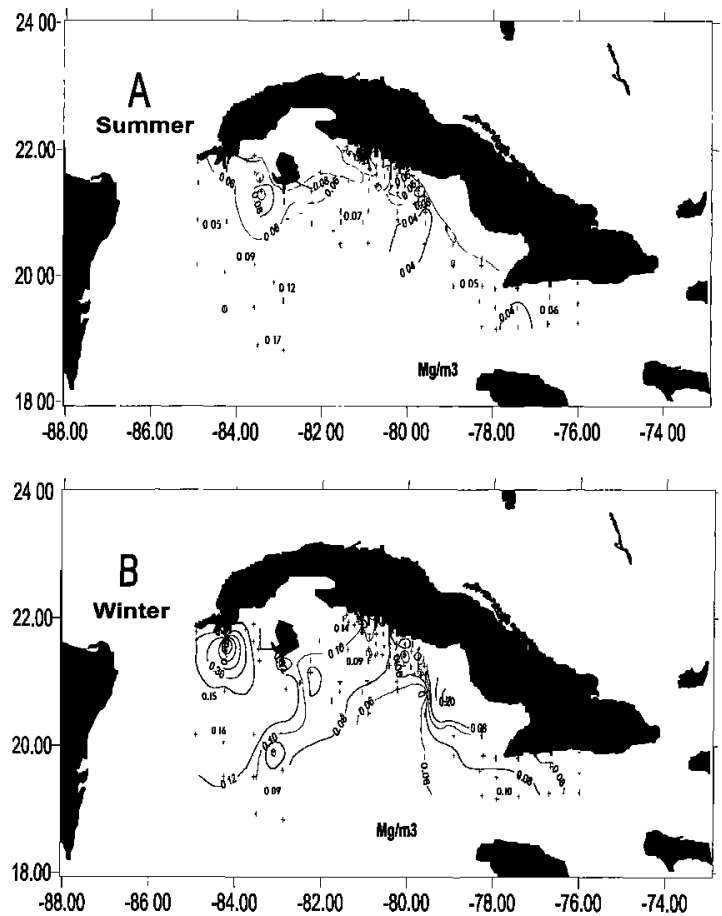

Figure 6. In Situ phytoplankton pigment concentration (mg $\mathrm{m}^{-3}$ ) south of Cuba (a) in summer (Ulises cruises 4 and 5 in 1989) and (b) in winter (Ulises cruises 2 and 31988 and 1989). The pluses are oceanographic stations.

tween mid-August and mid-September. Two hurricanes affected area I-a, two affected area I-b, one affected area I-c, five affected area II, three affected area III, and none affected area IV. However, 1980 was a very active season in the Atlantic (4 depressions and 12 hurricanes). In the study area the following events were registered: two in area I-a, two in area I-b, none in area I-c, three in area II, none in area III, and one in area IV. We experienced Hurricane Allen, one of the most intense of the twentieth century, with maximum winds $>91 \mathrm{~m} \mathrm{~s}^{-1}$. Allen lasted from August 2 through 11 and crossed areas IV, I-a, I-b, and II. It attained maximum intensity in the Gulf of Mexico. The cooling effect of a hurricane on SST may last up to 20 days, and if the hurricane is especially intense, the signal may remain up to 50 days [Tunegolobes, 1976]. Given that 1980 also experienced a very active cold front winter season, the waters within our region were mixed vigorously and repeatedly. We believe this to be the reason for the sustained blooming of phytoplankton detected as the maximum observed in Figure 8 starting July 1980 and ending approximately in June 1981. Again, 1981 was a very active season in the Atlantic, with 6 depressions and 11 hurricanes. However, the impact on the study area was weak, with only three hurricanes in area I-a, one in area I-b, and none in the Areas I-c, II, III, and IV. The season began early, in May, with storms that affected area I-a. The 1982 cyclone season was weak, with 4 depressions and 5 hurricanes. In the study area a single depression was registered in June in area I-b of the Gulf of Mexico. An even weaker season was experienced in 1983 ( 3 depressions and 3 hurricanes). In the study area a single case was registered in August that affected areas I-c, I-b, and II. A lot of activity occurred in the Atlantic in 1984, with 4 depressions and 12 hurricanes, but almost no activity occurred in the study area. A depression affected area I-c. Then 1985 was a very active season ( 2 de- pressions and 11 hurricanes), with several hurricanes in the Gulf of Mexico. In the study areas none affected area I-a, four affected I-b, none affected area I-c, two were observed in area II, two were in area III, and none were in area IV. Finally, 1986 showed weak activity ( 3 depressions and 6 hurricanes). Only one hurricane affected area II.

\subsection{Meteorological Frontal Systems}

The frontal systems in 1978-1986 were examined using synoptic weather maps on file at INSMET. From 67 winter seasons analyzed the annual average number of cold fronts that affected Cuba was 19.9. In winters 1980-1981 and 1982-1983 the incidence of cold fronts increased above the norm, with 48 and 43 cases, respectively. The cold fronts we identified for 1979-1986 winters within the biogeographic areas are shown in Table 5.

Although 1980-1981 had more cold front systems than 1982-1983, the latter season showed better defined fronts over the Gulf of Mexico (areas II and I-b), the straits north of Cuba, and a the northwestern Caribbean (areas I-a and I-c). Fronts also reached waters southeast of Cuba (area III) in 1982-1983 with almost twice the frequency of that of the previous years. Also, between October 1982 and March 1983, 19 extratropical low-pressure systems formed in the Gulf of Mexico. These winter storms traveled farther to the south than normal, causing high winds in our study areas.

The frequency distribution of cold fronts in 1980-1981 showed a maximum in December-February, but in 1982-1983, peak winter storm activity stretched through March (Figure 9). Even though the number of cold fronts decreased thereafter, in both cases the season of fronts extended until May. Therefore in 1980-1981 and 1982-1983 the oceanic environment around Cuba experienced prolonged periods of strong winds. These generated intense surf and vertical turbulent mixing.

During ENSO events, tropical hurricane formation in the Atlantic is inhibited [Gray and Sheaffer, 1991], but the frequency of extratropical low-pressure systems increases in the Gulf of Mexico during winter [Cárdenas and Naranjo Díaz, 2000a]. We hypothesize that the increased frequency of storms associated with such cold fronts led to the high concentration of pigments observed for these two winter seasons (1980-1981 and 1982-1983). The effect is very pronounced in the region dunging the ENSO event of 1982-1983.

\subsection{Variation of the Sea Surface Temperature}

On the basis of World Meteorological Organization (WMO) reports [WMO, 1996] the period 1978-1986 was characterized by positive global SST anomalies [Bottomley et al., 1990]. For our study area around Cuba (Figure 1), during the CZCS period (1978-1986), marked positive anomalies in SST were observed in $1980-1983\left(\sim 0.10^{\circ}-0.27^{\circ} \mathrm{C}\right.$; Figure 10$)$. The periods 1977-1978, 1982-1983, and 1986-1987 are classified as

Table 4. Phytoplankton Data in Surface Waters South of Cuba Based on in Situ Observations Carried out Aboard the R/V Ulises Between 1988 and 1989

\begin{tabular}{lccc}
\hline & $\begin{array}{c}\text { Number } \\
\text { of Stations }\end{array}$ & $\begin{array}{c}\text { Average } \\
\text { Number } \\
\text { of Species }\end{array}$ & $\begin{array}{c}\text { Average Chlorophyll } \\
\text { Concentration, } \\
\mathrm{mg} \mathrm{m}^{-3}\end{array}$ \\
\hline Winter & 150 & 73 & 0.117 \\
Summer & 153 & 62 & 0.074 \\
\hline
\end{tabular}




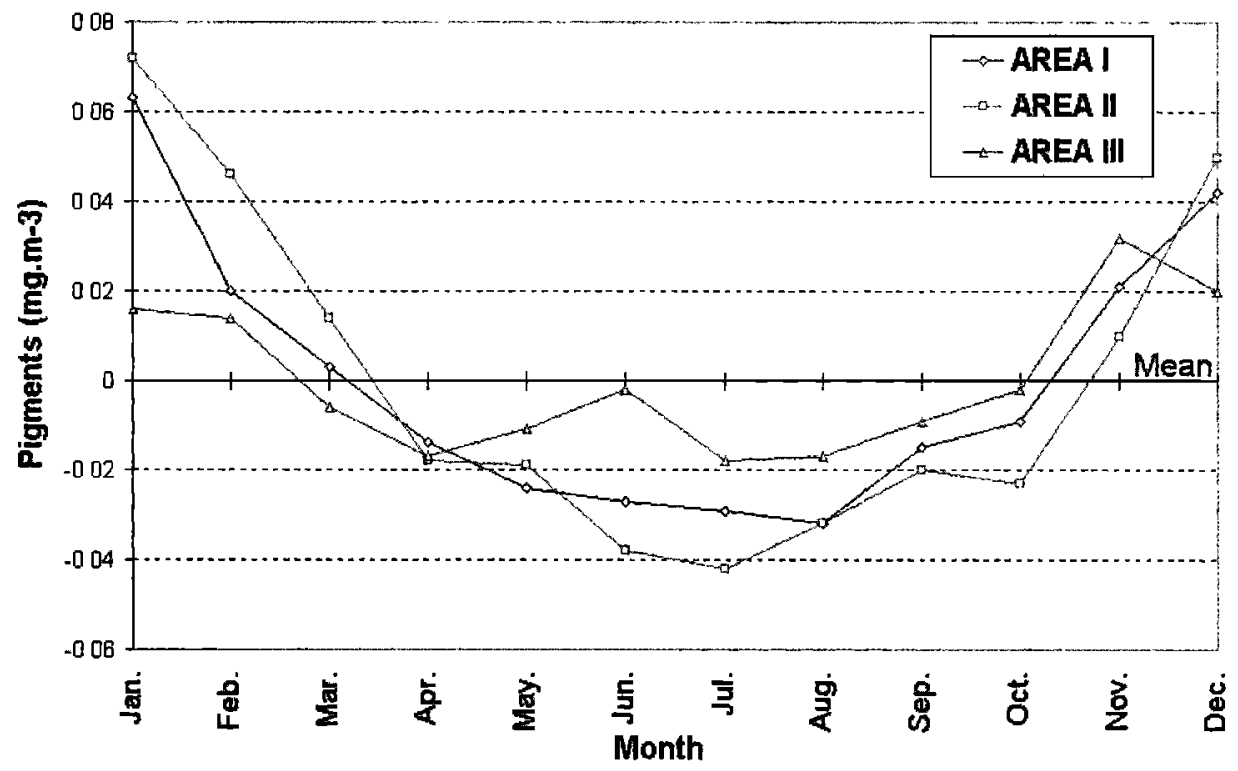

Figure 7. Seasonal anomalies in pigment concentration in areas I, II, and III relative to the annual mean value (1978-1986).

ENSO years. The event of 1982-1983 was, until recently, considered the strongest of the century [cf. Hanson and Maul, 1991]. Mean SST around Cuba was $27.53^{\circ} \mathrm{C}$ between 1979 and 1986 , with a maximum of $29.00^{\circ} \mathrm{C}$ in August-September and a minimum of $25.84^{\circ} \mathrm{C}$ in February.

Within this extended period of positive SST anomalies the periods of the lowest annual SST anomalies coincide with the periods of high anomalies in pigment concentration in the Caribbean Sea and the Gulf of Mexico. Negative SST anomalies occurred from the second semester of 1984 through October of 1986.

Weather was severe in Cuba during the 1982-1983 ENSO episode, with reports of flooding by storm surges along the
Havana coast [Rodriguez et al., 1986], the scarcity of some marine fish species in Cuban waters, and the presence of some coelenterates species (jellyfish) from other regions of the Caribbean around Cuba (B. Hernández, personal communication, 1996).

We applied a cross-correlation analysis between SST anomalies in the Pacific Ocean (El Niño 3 region, see below) and SST anomalies around Cuba in the double line box shown in Figure 1. A high correlation was obtained (0.71) with a 4 month lag relative to the beginning of the ENSO in the Pacific. This agrees with the 4-5 month lag identified by Enfield and Mayer [1997] for the Caribbean basin. The correlation of these phenomena in the Caribbean and the Gulf of Mexico with

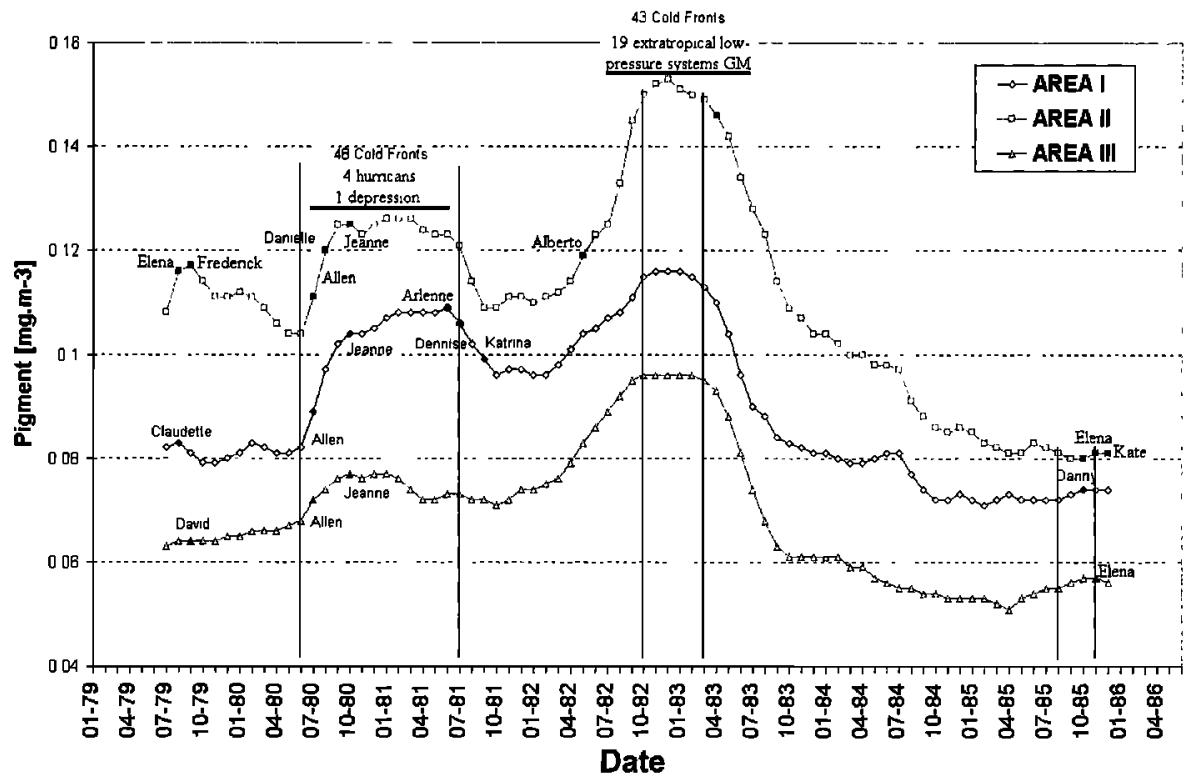

Figure 8. Twelve month moving average of pigment concentration in areas I, II, III (1978-1986). The 12 month moving average filter removes the seasonal pattern of Figure 7. For each area the curves are annotated with the occurrence of hurricanes, cold fronts, and extratropical low-pressure systems. 
Table 5. Incidence of Cold Front Systems in the Studied Areas During Winters 1979-1986

\begin{tabular}{lccccccc}
\hline & Cuba & $\begin{array}{c}\text { Area } \\
\text { I-a }\end{array}$ & $\begin{array}{c}\text { Area } \\
\text { I-b }\end{array}$ & $\begin{array}{c}\text { Area } \\
\text { I-c }\end{array}$ & $\begin{array}{c}\text { Area } \\
\text { II }\end{array}$ & $\begin{array}{c}\text { Area } \\
\text { III }\end{array}$ & $\begin{array}{c}\text { Area } \\
\text { IV }\end{array}$ \\
\hline $1979-1980$ & 20 & 20 & 35 & 33 & 36 & 12 & 3 \\
$1980-1981$ & 48 & 29 & 48 & 44 & 48 & 11 & 6 \\
$1981-1982$ & 16 & 15 & 36 & 36 & 36 & 7 & 2 \\
$1982-1983$ & 43 & 30 & 43 & 42 & 43 & 21 & 3 \\
$1983-1984$ & 25 & 25 & 36 & 34 & 36 & 15 & 5 \\
$1984-1985$ & 20 & 16 & 20 & 20 & 20 & 13 & 6 \\
$1985-1986$ & 18 & 18 & 18 & 18 & 18 & 11 & 3 \\
\hline
\end{tabular}

Maxima were observed in 1980-1981 and in 1982-1983.

phenomena in the Pacific is probably due primarily to the connection effected by variations in the Trade Winds and in the southern migration of the jet stream. The changes in the average speed of the wind affect the temperatures in the mixed layer [Enfield and Mayer, 1997].

\subsection{ENSO Event}

The tropical Pacific Ocean has been subdivided, according to the SST anomalies associated with ENSO events, as Niño 1-2 (for anomalies contained within $0^{\circ}-10^{\circ} \mathrm{S}, 80^{\circ}-90^{\circ} \mathrm{W}$ ), Niño $3\left(5^{\circ} \mathrm{N}-5^{\circ} \mathrm{S}, 90^{\circ}-150^{\circ} \mathrm{W}\right)$, Niño $4\left(5^{\circ} \mathrm{N}-5^{\circ} \mathrm{S}, 160^{\circ}-150^{\circ} \mathrm{W}\right)$, and Niño $3-4\left(5^{\circ} \mathrm{N}-5^{\circ} \mathrm{S}, 120^{\circ}-170^{\circ} \mathrm{W}\right)$. The Southern Oscillation is defined by the pressure difference between Darwin $\left(12.4^{\circ} \mathrm{S}\right.$, $\left.139^{\circ} \mathrm{W}\right)$ in northern Australia and Tahiti $\left(17.5^{\circ} \mathrm{S}, 149.6^{\circ} \mathrm{W}\right)$ in the South Pacific [Trenberth, 1984]. In general, an ENSO event implies the simultaneous occurrence of the two phenomena: $\mathrm{El}$ Niño, of oceanic character, and the Southern Oscillation, of atmospheric character [Chen, 1990].

Much has been written on the relationship between ENSO and precipitation anomalies in various regions of the globe. Clearly, climatic impact is not limited to the equatorial area of the Pacific [see, e.g., Yazunari, 1987; Rassmuson and Carpenter,

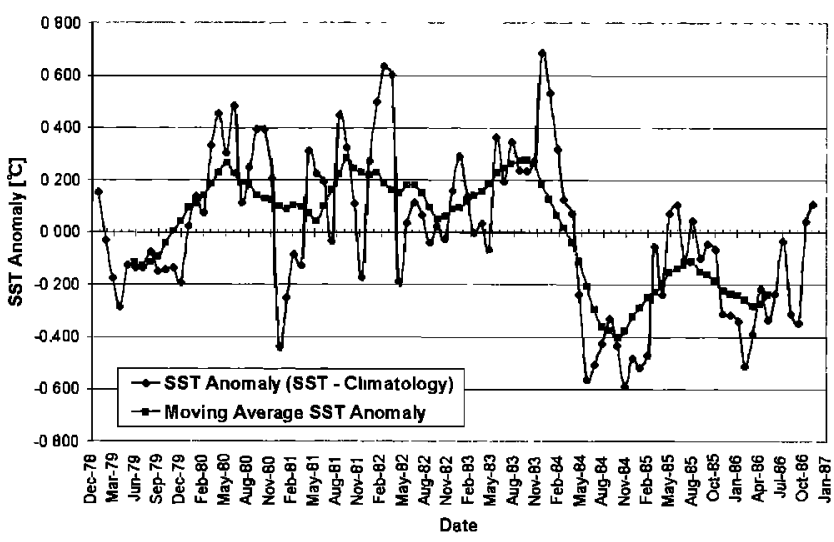

Figure 10. Sea surface temperature (SST) anomaly and SST anomaly moving average (seasonality removed) in the grid of Cuba (1979-1986).

1982; Hastenrath and Wolter, 1992]. As for the Intra-Americas Sea, Hanson and Maul [1991] demonstrated that positive anomalies in precipitation over Florida and El Niño are linked. According to Hanson and Maul [1991], 30\% of the interannual variance in precipitation occurs at frequencies of 5-6 years, similar to the frequency of recurrence of ENSO. Ropelewski and Halpert [1987] point out that for the northwestern Caribbean Sea and the Gulf of Mexico, positive anomalies in precipitation extend from October of the ENSO year until March of the following year. In the peculiar case of the 1982-1983 ENSO; Enfield [1989] and Canby [1984] reported unusually high precipitation south of the United States and in the northern Caribbean.

The 1982-1983 episode is reported to have started as early as May 1982 [Cárdenas and Naranjo Díaz, 2000b], but Silva [1988] suggest that it started in November 1982. Wyrtki [1985] suggests that the appearance of positive anomalies in sea level

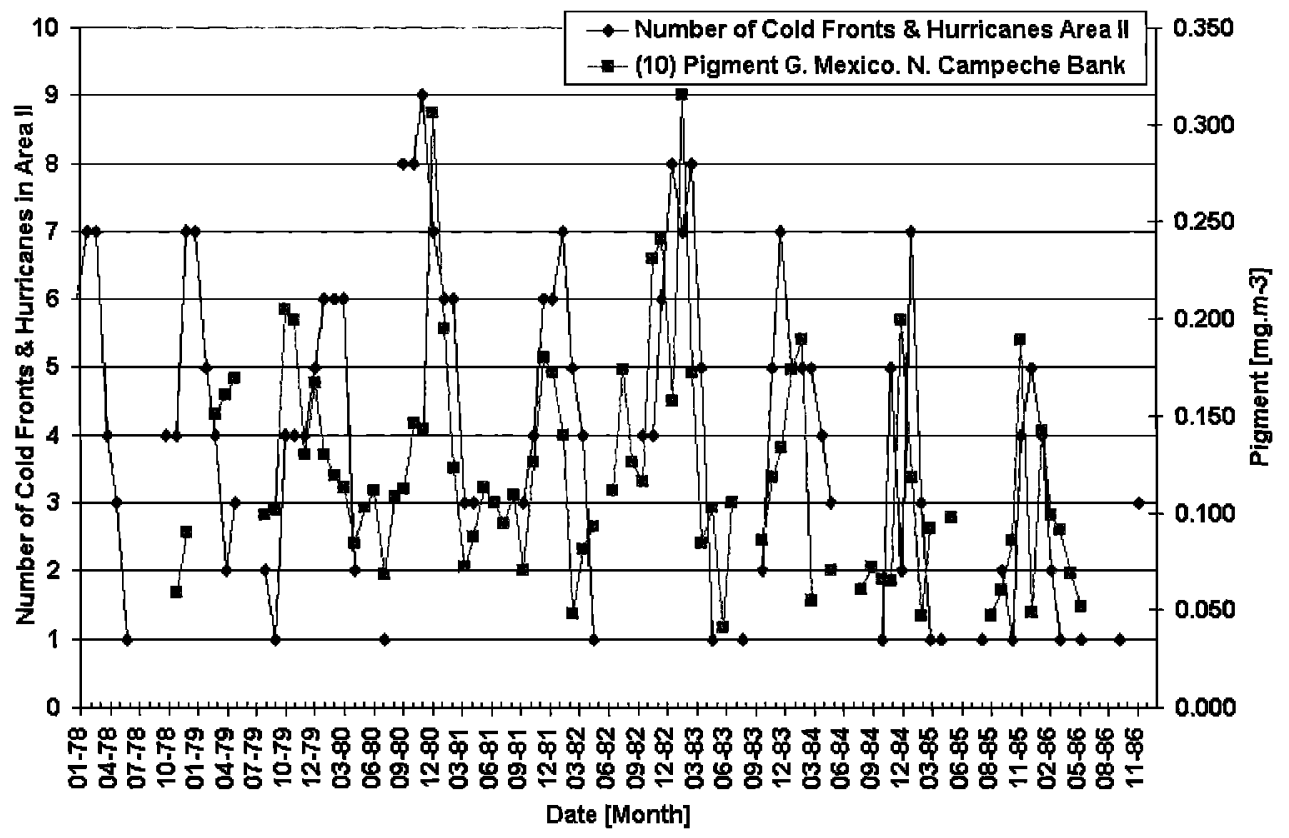

Figure 9. Number of cold fronts and hurricanes in area II (central Gulf of Mexico) and pigment concentration at station 10 (north Campeche Bank, Gulf of Mexico) from 1978 to 1986. 
Table 6. Correlation Coefficients Between Monthly Pigment Anomalies $\left(\mathrm{PZ}_{I J}\right)$ in Areas of the Caribbean and the Gulf of Mexico, the Empirical Index (INDI) of Occurrence of ENSO, and the SST Anomalies (ATSM) in Regions of the Pacific and the Atlantic

\begin{tabular}{lcccc}
\hline & PZ I & PZ II & PZ III & PZ IV \\
\hline INDI & $0.3939^{\mathrm{a}}$ & $0.5185^{\mathrm{a}}$ & $0.5886^{\mathrm{a}}$ & $0.4893^{\mathrm{a}, \mathrm{b}}$ \\
ANIN12 & $0.3072^{\mathrm{c}}$ & $0.3328^{\mathrm{c}}$ & $0.4627^{\mathrm{a}}$ & $0.3515^{\mathrm{c}}$ \\
ANIN3 & $0.4589^{\mathrm{a}, \mathrm{b}}$ & $0.5250^{\mathrm{a}, \mathrm{b}}$ & $0.6731^{\mathrm{a}}$ & $0.4706^{\mathrm{a}}$ \\
ANIN4 & $0.2814^{\mathrm{c}}$ & $0.3700^{\mathrm{a}}$ & $0.6110^{\mathrm{a}}$ & $0.3799^{\mathrm{c}}$ \\
ANIN34 & $0.3974^{\mathrm{a}}$ & $0.5066^{\mathrm{a}}$ & $0.6985^{\mathrm{a}, \mathrm{b}}$ & $0.4672^{\mathrm{a}}$ \\
ANNATL & $\mathbf{0 . 1 3 9 3}$ & 0.2359 & 0.1140 & 0.0992 \\
ANSATL & -0.2143 & -0.2006 & $-0.2866^{\mathrm{c}}$ & -0.0781 \\
ANTROP & $\mathbf{0 . 4 1 4 4 ^ { \mathrm { a } }}$ & $0.4724^{\mathrm{a}}$ & $0.6307^{\mathrm{a}}$ & $0.4795^{\mathrm{a}}$ \\
\hline
\end{tabular}

aStatistical significance at $\alpha=0.001$.

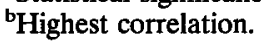

'Statistical significance at $\alpha=0.01$. around $5-10 \mathrm{~cm}$ in the western Pacific between January and March of 1982 mark the initiation. He also reports drastic anomalies in sea level (of up to $+17 \mathrm{~cm}$ ) in the western Pacific in July 1982. This period coincides with the point at which pigments start rising in the western Caribbean Sea and the Gulf of Mexico (Figure 8).

To examine the relationship between variations in the concentration of pigments in our study area and ENSO, we used an empirical index (INDI) [Cárdenas and Naranjo Díaz, 2000b] to quantify the correlation between the monthly SST anomalies (derived from the National Center of Environmental Predictions data) in the Niño 1-2, Niño 3, Niño 4, and Niño 3-4 areas (ANIN12, ANIN3, ANIN4, and ANIN34, respectively), SST anomalies in the North Atlantic $\left(5^{\circ}-20^{\circ} \mathrm{N}, 30^{\circ}-60^{\circ} \mathrm{W}\right)$ (ANNATL), in the South Atlantic $\left(0^{\circ}-20^{\circ} \mathrm{S}, 10^{\circ} \mathrm{E}-30^{\circ} \mathrm{W}\right)$ (ANSATL), and in the tropical belt $\left(10^{\circ} \mathrm{S}-10^{\circ} \mathrm{N}, 0^{\circ}-360^{\circ}\right)$
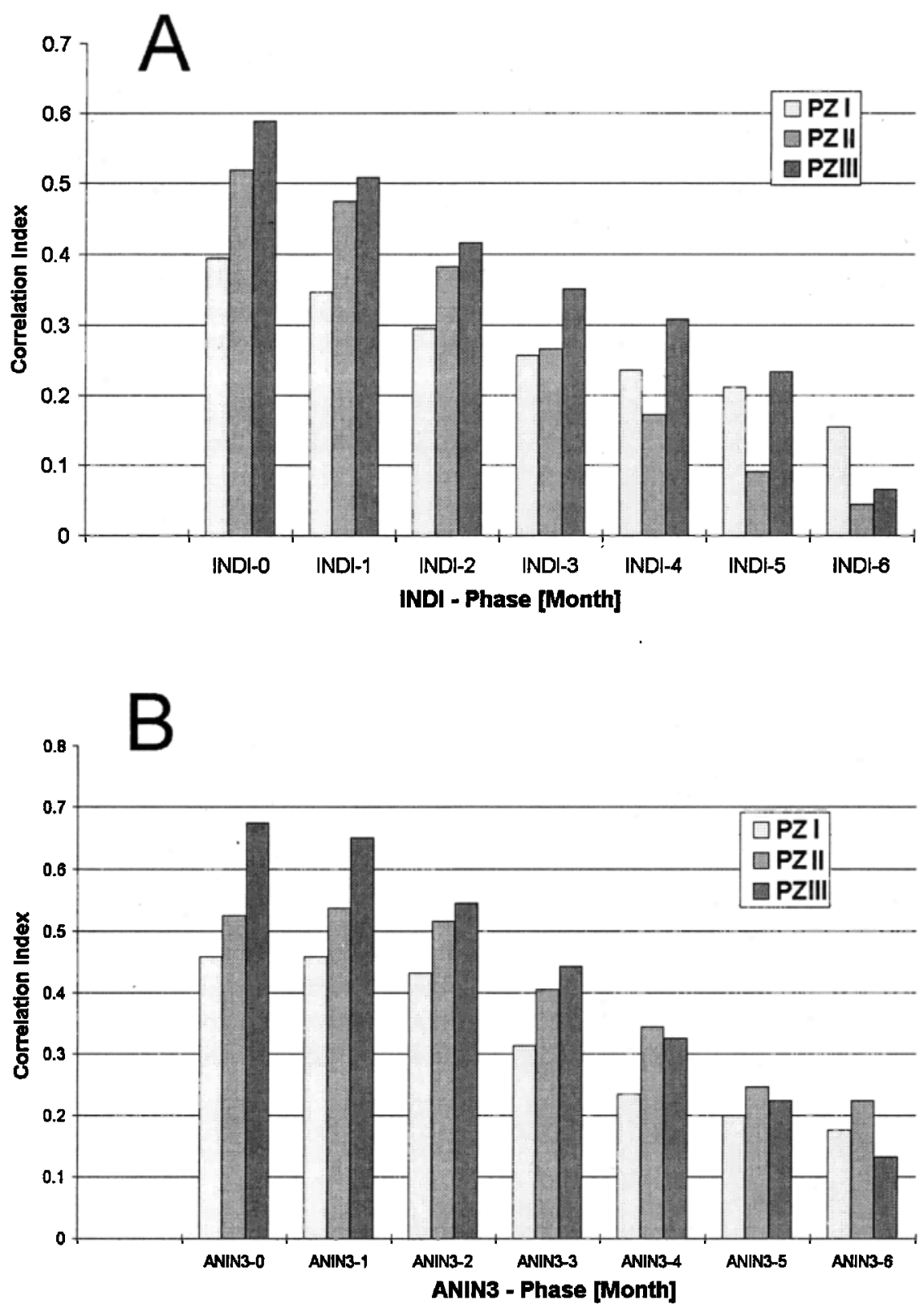

Figure 11. Phase lags in the correlation index between (a) the monthly anomaly of pigment concentration for areas in the Caribbean Sea and the Gulf of Mexico, the empirical index (INDI) of ENSO occurrence, and (b) the monthly anomaly of SST in El Niño 3 region (ANIN3) in the Pacific Ocean. 


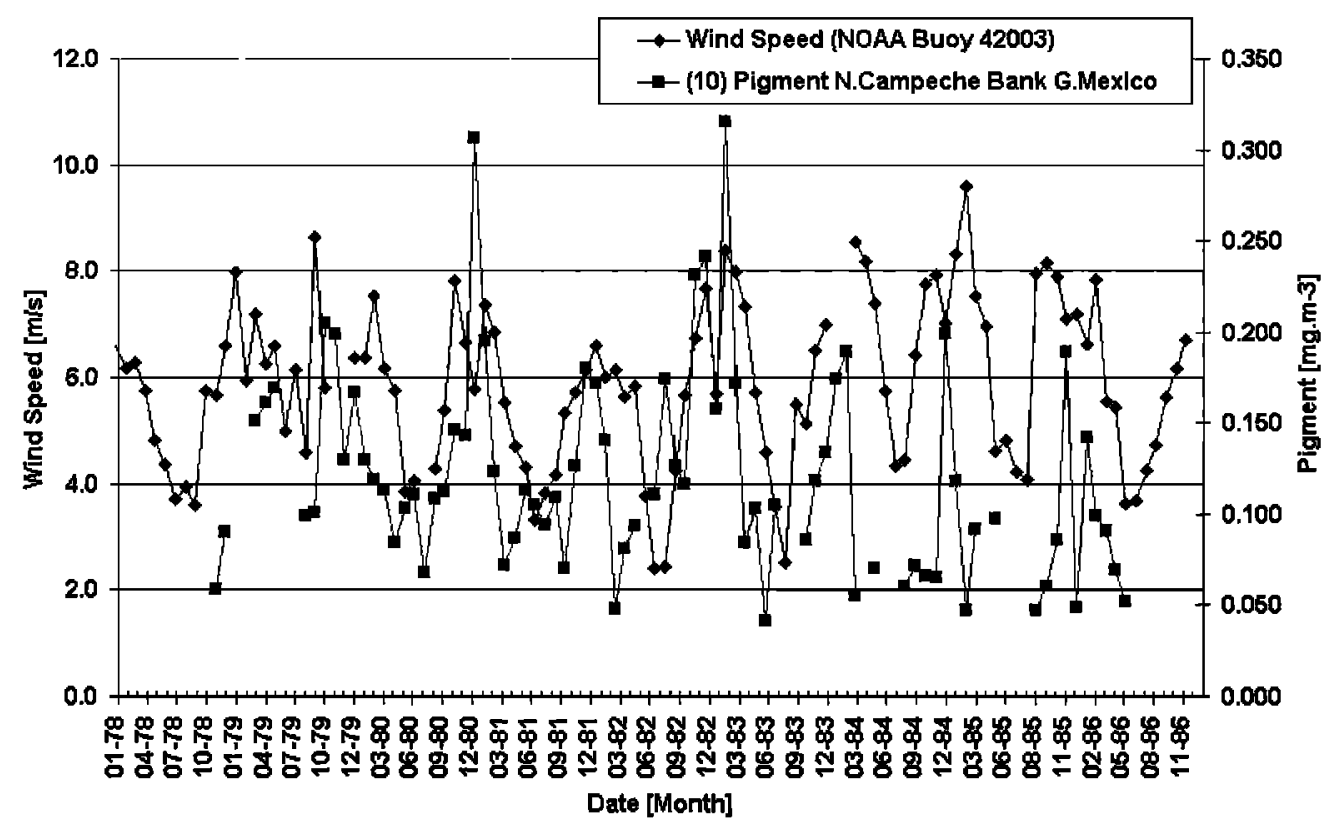

Figure 12. Pigment concentration at station 10 (north Campeche Bank, Gulf of Mexico) and wind speed at National Oceanic and Atmospheric Administration buoy $42003\left(25.94^{\circ} \mathrm{N}, 85.91^{\circ} \mathrm{W}\right)$ in the eastern Gulf of Mexico.

(ANTROP) with the monthly anomalies of pigments $\left(\mathrm{PZ}_{I J}\right)$ for areas obtained from the CZCS images (Table 6).

$$
\begin{aligned}
\text { INDI }=-M(\mathrm{AMTSM}) M(\mathrm{SOI}) & M(\mathrm{SOI})<0 \\
\text { INDI }=M(\mathrm{AMTSM}) M(\mathrm{SOI}) & M(\mathrm{SOI})>0,
\end{aligned}
$$

where AMTSM is the monthly SST anomaly of an area, SOI is the Southern Oscillation Index, and $M$ is the moving average of the last 3 months of each index of occurrence of ENSO.

$$
\mathrm{PZ}_{I J}=\left(P_{I J}-\mathrm{Pcl}_{J J}\right) / \mathrm{Pcl}_{I J},
$$

where $\mathrm{PZ}_{I J}$ is the anomaly of pigments in area $I$ for the month $J ; P_{I J}$ is the concentration of pigments in area $I$ in month $J$; and $\mathrm{Pcl}_{I J}$ is the climatological average of the concentration of pigments for area $I$ for every month $J$ between 1978 and 1986.

A significant correlation is observed between pigment in our area of study and the SST anomalies in ANIN3 and ANIN34, in ANTROP, and with INDI. Areas I and II are better correlated with ANIN3, area III is better correlated with ANIN34, and area IV is better correlated with INDI (Table 6). These correlations suggest that a relationship exists between ENSO and the concentration of pigments in the western Caribbean Sea and the Gulf of Mexico.

Given the strong relationship between these phenomena and the desire to forecast effects in our region, we computed time lag correlation functions between the monthly $\mathrm{PZ}$ by areas in the Caribbean and the Gulf of Mexico, the INDI and SOI, and the AMTSM. Lags of up to 12 months were examined. In Figure 11, the INDI and ANIN3 functions are shown for the Pacific.

We found maximum correlation for " 0 month lag" between the monthly anomaly of surface pigment concentration for areas in the Caribbean Sea and the Gulf of Mexico and ENSO events and with the monthly anomaly of SST in ANIN3 in the Pacific Ocean. ENSO anomalies may precede the pigment anomalies in the IAS by at least 3 months (Figure 11).
The pigment concentration anomaly in 1980-1981 seems to be primarily related to an extended stormy winter season. However, in 1980-1981 we also observed an intensified cyclone season that included Hurricane Allen (one of the most intense in the century), and this may have initiated the positive pigment anomaly. The pigment anomaly of 1982-1983 is related to an ENSO of great intensity. Over this period, cold fronts reached the region with almost twice the frequency of previous years, and more low-pressure systems formed in the Gulf of Mexico and traveled farther to the south than normal, causing high winds in our study areas.

Figure 9 shows the relationship between the time variation of pigment concentration at station 10 in the Gulf of Mexico and the occurrence of intense meteorological phenomena (tropical hurricanes and cold frontal systems). We also compared the pigment series to wind speed at National Data Buoy Center buoy station 42003 in the Gulf of Mexico (Figure 12). The relationship between the wind and pigment concentration is clear. Hurricanes and cold frontal systems in the region stimulate brief but intense winds, waves, and rain and therefore increase the vertical mixing of the photic layer and fertilize it. The 1982-1983 ENSO event significantly decreased the primary productivity in the oriental Pacific. According to Chávez and Barber [1985] the losses in biomass in the 300 days that the event lasted were of around a gigaton. The consequences for the northwestern Caribbean and the Gulf of Mexico were, in contrast, an increase in the pigment concentration (phytoplankton biomass) of the upper layers.

\section{Conclusions}

CZCS images confirm the seasonality in phytoplankton concentration in the northwestern Caribbean Sea and the Gulf of Mexico, with maxima during winter and minima during summer. The higher concentration of pigments in winter is related 
to the occurrence of meteorological frontal systems that increase vertical turbulence and to thermal convective overturn.

Four areas were identified by similarity in temporal variability. Area I includes waters southwest of Cuba, Yucatan Channel, and Florida Strait; area II includes the central region of the Gulf of Mexico; area III covers waters off eastern Cuba, Windward Passage, and the Sargasso Sea; area IV includes the central Caribbean to the south of Jamaica and Hispaniola (Figure 1).

The spatial and temporal variability of pigment concentration in the Gulf of Mexico is larger than in the western Caribbean, increasing from east to west and from south to north. This pattern is due to the difference in thermal stratification across the region, which limits vertical mixing of nutrients, the intrusion of nutrient-poor waters from the western Caribbean into the Gulf of Mexico, the more intense and frequent occurrence of cold fronts and extratropical low-pressure systems in the Gulf of Mexico, which increase vertical mixing, and the nutrient contribution from the Mississippi River (a minor cause).

Two remarkable maxima in the concentration of pigments in the western Caribbean Sea and the Gulf of Mexico occurred in 1980-1981 and in 1982-1983. A relationship exists between the time variation of these maxima and the occurrence of intense meteorological phenomena (hurricanes, frontal systems, and extratropical low-pressure systems). These phenomena in the region stimulate an increase in the wind speed, waves, and rain and thereby increase the vertical mixing of the photic layer and fertilize it. The first maximum, 1980-1981, was affected by an intense hurricane season (including Hurricane Allen, one of the most intense in the century) and a very active winter season. The second maximum is related to an ENSO of great intensity. In this period, cold fronts reached the region with almost twice the frequency of the previous year, and more low-pressure systems formed in the Gulf of Mexico. These patterns are indicative of a connection between the ENSO and the concentration of surface pigments in the western Caribbean Sea and the Gulf of Mexico.

Acknowledgments. We thank to Isidro Salas García from the Meteorology Institute of Cuba and Benigno Hernández de la Torre for their assistance in obtaining and processing data. Support for this study was derived in part from the Cuban National Global Change Studies Program and NASA grant NAGW 3483 to F. E. Muller-Karger, University of South Florida.

\section{References}

Academy of Sciences of Cuba, New National Atlas of Cuba, Havana, Cuba, XXIV.3.4 pp., 1989.

Barale, V., C. R. McClean, and P. Malanotte-Rizzol, Space and time variability of the surface color field in the northern Adriatic Sea, $J$. Geophys Res., 91, 12,957-12,974, 1986.

Bottomley, M., C. K. Folland, J. Hsiung, R. E. Newell, and D. E. Parker, Global Ocean Surface Temperature Atlas, $20 \mathrm{pp}$. and 313 plates, Dept. of Earth, Atmos., and Planet. Sci., Mass. Inst. of Technol., Cambridge, 1990.

Canby, T. Y., Ei Niño's ill wind, Natl. Geogr., 165, 144-183, 1984.

Cárdenas Pérez, P. A., and L. R. Naranjo Díaz, Impacto y modulación de efectos del ENOS sobre elementos climáticos en Cuba, Anal. Fís. Esp., in press, 2000a.

Cárdenas Pérez, P. A., and L. R. Naranjo Díaz, Un índice empírico de occurrencia de ENOS: Papel en la predictabilidad de elementos climáticos, Atmósfera, in press, $2000 \mathrm{~b}$.

Chavez, F. P., and R. T. Barber, Plankton production during El Niño, in International Conference on the TOGA Scientrfic Program, WCRP Publ. Ser., vol. 4, pp. 23-32, World Meteorol. Org., Geneva, 1985.
Chen, G., A study of interrelation between El Niño, precipitation and astronomical motion, WMO Tech. Doc. 363, pp. 15-18, World Meteorol. Org., Geneva, 1990.

Corredor, J. E., Aspects of phytoplankton dynamics in the Caribbean Sea and adjacent regions, in Symposium on Progress in Marine Research in the Caribbean and Adjacent Regions, Fish Rep. 200, pp. 101-114, Food and Agric. Org., Rome, 1977.

Deuser, W. G., F. E. Müller-Karger, R. H. Evans, O. B. Brown, W. E. Esaias, and G. C. Feldman, Surface-ocean color and deep-ocean carbon flux: How close a connection? Deep Sea Res., Part I, 37, 1331-1343, 1990.

Enfield, D. B., El Niño, past and present, Rev. Geophys., 27, 159-187, 1989.

Enfield, D. B., and M. A. Mayer, Tropical Atlantic sea surface temperature variability and its relation to El Niño/Southern Oscillation, J. Geophys. Res., 102, 929-946, 1997.

Evans, R. H., and H. R. Gordon, CZCS "system calibration": A retrospective examination, J. Geophys. Res., 99, 7293-7307, 1994.

Fernández, L., and A. Chirinos, Atlas Oceanográfico del Archipiélago Sabana-Camaguey, Inst. Cubano de Hidrog., Havana, Cuba, 1993.

Fernández, M., R. M. Hidalgo, D. López, I. García, and I. Penié, Caracterización hidroquímica de la Fosa del Jagua y la zone económica exclusive al Sur de Cuba, in Archivo Cientifico, Inst. de Oceanol., Acad. de Cienc. de Cuba, Havana, ACC, 1990.

Gordon, A. L., Circulation of the Caribbean Sea, J. Geophys. Res., 72, 6207-6223, 1967

Gordon, H. R., and M. Wang, Retrieval of water-leaving radiance and aerosol optical thickness over the oceans with SeaWiFS: A preliminary algorithm, Appl. Opt., 33, 443-452, 1994.

Gordon, H. R., D. K. Clark, J. W. Brown, O. B. Brown, and R. H. Evans, Satellite measurement of the phytoplankton pigment concentration in the surface waters of a warm core Gulf Stream ring, $J$. Mar. Res., 40, 491-502, 1982.

Gordon, H. R., D. K. Clark, J. W. Brown, O. B. Brown, R. H. Evans, and W. W. Broenkow, Phytoplankton pigment concentrations in the Middle Atlantic Bight: Comparison of ship determinations and CZCS estimates, Appl. Opt., 22, 20-35, 1983a.

Gordon, H. R., J. W. Brown, O. B. Brown, R. H. Evans, and D. K. Clark, Nimbus 7 CZCS: Reduction of its radiometric sensitivity with time, Appl. Opt., 22, 3929-3931, 1983b.

Gordon, H. R., O. B. Brown, R. H. Evans, J. W. Brown, R. C. Smith, K. S. Baker, and D. K. Clark, A semi-analytic radiance model of ocean color, J. Geophys. Res., 93, 10,909-10,924, 1988.

Gray, W. M., and J. D. Sheaffer, El Niño and QBO influences on tropical cyclone activity, in Telecommunication Linking Worldwide Climate Anomalies, edited by R. W. Katz and N. Nicholls, pp. 257284, Cambridge Univ., Press, New York, 1991.

Hanson, K., and G. A. Maul, Florida precipitation and the Pacific El Niño 1895-1989. Fla. Scl., 54, 160-168, 1991.

Hastenrath, S., and K. Wolter, Large scale patterns and long-term trends of circulation variability associated with Sahel rainfall anomalies, J. Meteorol. Soc. Jpn., 70, 1045-1056, 1992.

Hochman, T. H., F. E. Muller-Karger, and J. Walsh, Interpretation of the Coastal Zone Color Scanner signature of the Orinoco River Plume, J. Geophys. Res., 99, 7443-7455, 1994.

Jeffrey, S. W., and G. F. Humphrey, New spectrophotometric equations for determining chlorophyll $\mathrm{a}, \mathrm{b}$, and $\mathrm{c}$ in higher plants, algae and natural phytoplankton, Biochem. Physiol., 167, 191-194, 1975.

Jromov, N. S., Investigations of the plankton in the Gulf of Mexico and the Caribbean Sed, in Soviet-Cuban Fishing Investigations (n Russlan), vol. 1, pp. 39-57, Pish. Prom., Moscow, 1967.

Koblentz-Mishke, O. I., and V. I. Vedernikov, Primary production, Oceanologia, in Biology of the Ocean (in Russian), vol. 2, pp. 183209, Nauka, Moscow, 1977a.

Koblentz-Mishke, O. I., and V. I. Vedernikov, Handbook of Methods in Aquatic Microbiology (In Russian), Publish, Moscow, 1977b.

Margalef, R., El Ecosistema pelágico del Mar Caribe, Memo. 29, pp. 5-36, Fundación Ĺa Salle," Caracas, Venezuela, 1969.

Maul, G. A., and F. M. Vukovich, The relationship between variations in the Gulf of Mexico loop current and Strait of Florida volume transport, J. Phys. Oceanogr., 23, 785-796, 1993.

McClain, C. R., et al., SeaWiFS algorithms, part 1, NASA Tech. Memo., 104566, 38 pp., 1995.

Melo, N., R. Pérez, and S. Cerdeira, Variación espacio-temporal de los pigmentos del fitoplancton en zones del Gran Caribe, a partir de imágenes de satélite Nimbus 7 (CZCS), Avicennia, 3, 103-116, 1995. 
Merino, M., El afloramiento de Yucatán: Estructura y fertilización, Ph.D. thesis, Univ. Nacl. Autónoma de México, Mexico City, 1992. Morel, A., and L. Prieur, Analysis of variations in ocean color, Limnol. Oceanogr., 22, 709-722, 1977.

Müller-Karger, F. E., and R. Aparicio Castro, Mesoscale processes affecting phytoplankton abundance in the southern Caribbean Sea, Cont. Shelf Res., 14, 199-221, 1994.

Muller-Karger, F. E., J. J. Walsh, R. H. Evans, and M. B. Meyers, On the seasonal phytoplankton concentration and sea surface temperature cycles of the Gulf of Mexico as determined by satellites, $J$. Geophys. Res., 96, 12,645-12,665, 1991.

Müller-Karger, F. E., et al., Pigment distribution in the Caribbean Sea: Observations from Space, Prog. Oceanogr., 23, 23-64, 1989.

Oort, A. H., and E. M. Rasmusson, Atmospheric circulation statistıcs, NOAA Prof. Pap. 5, 323 pp., U.S. Govt. Print. Off., Washington, D. C., 1971

O'Reilly, J. E., S. Maritorena, B. G. Mitchell, D. A. Siegel, K. L. Carder, S. A. Garver, M. Kahru, and C. McClain, Ocean color chlorophyll algorithms for SeaWiFS, J. Geophys. Res., 103, 24,93724,953, 1998 .

Ortiz, R., Organismos ciclónicos extemporáneos, in Ser. Meteorol., vol. 5, pp. 10-20, Inst. de Meteorol., Acad. de Cienc. de Cuba, Havana, 1975.

Pérez, R., C. Gil, and S. Loza, Variabilidad espacio-temporal del fitoplancton y sus pigmentos en aguas oceánicas al Sur de Cuba, in Archivo Cientifico, Inst. de Oceanol., Acad. de Cienc. de Cuba, Havana, 1990.

Pérez, R., et al., Reporte de un frente hidrológico al NE de la Península de Yucatán. Manifestaciones físicas, químicas e hidrobiológicas, Bol. Soc. Meteorol. Cuba, 2, pap. ISSN-1025-921X, 1996.

Pérez, R., F. E. Müller-Karger, I. Victoria, and N. Melo, Cuban, Mexican, U.S. Researchers probing mysteries of Yucatan currents, Eos Trans. AGU, 80, 153, 158-159, 1999.

Rassmuson, E. M., and I. H. Carpenter, Variations in tropical sea surface temperature and surface wind fields associated with the Southern Oscillation/El Niño, Mon. Weather Rev., 110, 354-384, 1982.

Reynolds, R. W., A real-time global sea surface temperature analysis, J. Clim., 1, 76-86, 1988.

Reynolds, R. W., and D. C. Marsico, An improved real-time sea surface temperature analysis, J. Clim., 6, 114-119, 1993.

Rodríguez, M., C. González, and J. Valdés, Cronología de los frentes fríos que hen afectado a Cuba desde la temporada de 1916-1917 haste la temporada de 1982-1983, reporte de investigación, 15 pp., Inst. de Meteorol., Acad. de Cienc. de Cuba, Havana, 1984.

Rodríguez, E., I. Guerra, and J. C. Cárdenas, Cronología y análisis sinóptico de las penetraciones del mar en las provincial habaneras
1970-1986, paper presented at 1er Congreso Internacional sobre desastres naturales, Acad. de Cienc. de Cuba, Havana, 1986.

Ropelewski, C. F., and M. S. Halpert, Global and regional scale precipitation patterns associated with the El Nin̄o Southern Oscillation, Mon. Weather Rev., 115, 1606-1626, 1987.

Silva, N., Condiciones oceanográficas pre-Niño 1982/83, Cienc. Tec. Mar, 12, 3-31, 1988.

Sorokin, Y. I., Methods for phytoplankton concentration determination (in Russian), Guidrobiol. Zh., 15, 71-76, 1979.

Thomas, W. H., and G. Simmons, Phytoplankton production in the Mississippi delta, in Recent Sediments, Northwest Gulf of Mexico, pp. 103-116, Am. Assoc. of Pet. Geol., Tulsa, Okla., 1960.

Trenberth, K. T., Signal versus noise in the Southern Oscillation, Mon. Weather Rev., 112, 326-332, 1984.

Tunegolobes, V.P., Transformation of the oceanic thermal field in the path of a tropical hurricane: The example of the hurricane "Tess" 1975 (in Russian), Meteorol. Guidrologuia, 2, 60-66, 1976.

Victoria, I., A. Cabal, R. García, M. Hernández, and H. Puentes, Características oceanográficas de la Fosa de Jagua y de la zone económica exclusive al Sur de Cuba, in Archivo Científico, Inst. Oceanol., Acad. de Cienc. de Cuba, Havana, 1990.

Vinogradov, M. E., and E. A. Shushkina, Operation of the Pelagic Plankton Communities of the Ocean, in Russian, 240 pp., Nauka, Moscow, 1987.

World Meteorological Organization (WMO), WMO statement on the status of the global climate in 1995,WMO 838,11 pp., Geneva, 1996.

Wüst, G., Stratification and circulation in the Antillean Caribbean basins, part 1, Spreading and mixing of the water types, in Oceanographic Atlas, Columbia Univ. Press, New York, 1964.

Wyrtki, K., Sea level fluctuations in the Pacific during the 1982/83 El Niño, Geophys. Res. Lett., 12, 125-128, 1985.

Yazunari, T., Global structure of the El Niño/Southern Oscillation, part II, Time evolution, J. Meteorol. Soc. Jpn., 65, 91-102, 1987.

P. Cárdenas Pérez and I. Mitrani Arenal, INSMET, CITMA, Apdo. 17032. Casablanca, Regla, Habana 17, Ciudad de La Habana, Cuba. C.P. 12100

S. Cerdeira Estrada, N. Melo González, R. Pérez de los Reyes, and I. Victoria del Rio, IDO, CITMA, Ave. 1 ra. No. 18406 entre 184 y 186. Flores, Playa, Habana 21, La Habana, Cuba. C.P. 12100.

F. Müller-Karger, Department of Marine Science, University of South Florida, 140 Seventh Avenue, St. Petersburg, FL 33701. (carib@carbon.marine.usf.edu)

(Received July 8, 1998; revised November 24, 1999; accepted January 19, 2000.) 